\title{
A comparative study of aerosol microphysical properties retrieved from ground-based remote sensing and aircraft in situ measurements during a Saharan dust event
}

\author{
María José Granados-Muñoz ${ }^{1,2, a}$, Juan Antonio Bravo-Aranda ${ }^{1,2}$, Darrel Baumgardner $^{3}$, \\ Juan Luis Guerrero-Rascado ${ }^{1,2}$, Daniel Pérez-Ramírez ${ }^{4,5}$, Francisco Navas-Guzmán ${ }^{6}$, Igor Veselovskii ${ }^{7}$, \\ Hassan Lyamani $^{1,2}$, Antonio Valenzuela ${ }^{1,2}$, Francisco José Olmo ${ }^{1,2}$, Gloria Titos ${ }^{1,2}$, Javier Andrey ${ }^{8, b}$, \\ Anatoli Chaikovsky ${ }^{9}$, Oleg Dubovik ${ }^{10}$, Manuel Gil-Ojeda ${ }^{8}$, and Lucas Alados-Arboledas ${ }^{1,2}$ \\ ${ }^{1}$ Andalusian Institute for Earth System Research (IISTA-CEAMA), Avd. del Mediterráneo, \\ 18006, Granada, Spain \\ ${ }^{2}$ Dpt. Applied Physics, University of Granada, Fuentenueva s/n, 18071, Granada, Spain \\ ${ }^{3}$ Droplet Measurement Technologies, Boulder, CO 80301, USA \\ ${ }^{4}$ Mesoscale Atmospheric Processes Laboratory, NASA Goddard Space Flight Center, 20771, \\ Greenbelt, Maryland, USA \\ ${ }^{5}$ Universities Space Research Association, 21044, Columbia, Maryland, USA \\ ${ }^{6}$ Institute of Applied Physics (IAP), University of Bern, Bern, Switzerland \\ ${ }^{7}$ Physics Instrumentation Center of General Physics Institute, Troitsk, Moscow Region, \\ 142190, Russia \\ ${ }^{8}$ Instituto Nacional de Técnica Aeroespacial (INTA), Ctra. Ajalvir km. 4, \\ 28850 Torrejón de Ardoz, Spain \\ ${ }^{9}$ Institute of Physics, National Academy of Science, Minsk, Belarus \\ ${ }^{10}$ Laboratoire d'Optique Atmospherique, CNRS Universite de Lille 1, Bat P5 Cite scientifique, \\ 59655 Villeneuve d'Ascq CEDEX, France \\ a currently at: Table Mountain Facility, NASA/Jet Propulsion Laboratory, California, Institute of \\ Technology, Wrightwood, California, USA \\ b currently at: CNRM-GAME, Météo-France, Tolouse, France
}

Correspondence to: María José Granados-Muñoz (mamunoz@jpl.nasa.gov)

Received: 18 August 2015 - Published in Atmos. Meas. Tech. Discuss.: 9 September 2015

Revised: 25 February 2016 - Accepted: 29 February 2016 - Published: 18 March 2016

\begin{abstract}
In this work we present an analysis of aerosol microphysical properties during a mineral dust event taking advantage of the combination of different state-of-theart retrieval techniques applied to active and passive remote sensing measurements and the evaluation of some of those techniques using independent data acquired from in situ aircraft measurements. Data were collected in a field campaign performed during a mineral dust outbreak at the Granada, Spain, experimental site $\left(37.16^{\circ} \mathrm{N}, 3.61^{\circ} \mathrm{W}, 680 \mathrm{~m}\right.$ a.s.1.) on 27 June 2011. Column-integrated properties are provided by sun- and star-photometry, which allows for a continuous
\end{abstract}

evaluation of the mineral dust optical properties during both day and nighttime. Both the linear estimation and AERONET (Aerosol Robotic Network) inversion algorithms are applied for the retrieval of the column-integrated microphysical particle properties. In addition, vertically resolved microphysical properties are obtained from a multi-wavelength $\mathrm{Ra}$ man lidar system included in EARLINET (European Aerosol Research Lidar Network), by using both LIRIC (Lidar Radiometer Inversion Code) algorithm during daytime and an algorithm applied to the Raman measurements based on the regularization technique during nighttime. LIRIC retrievals 
reveal the presence of dust layers between 3 and $5 \mathrm{~km}$ a.s.l. with volume concentrations of the coarse spheroid mode up to $60 \mu \mathrm{m}^{3} \mathrm{~cm}^{-3}$. The combined use of the regularization and LIRIC methods reveals the night-to-day evolution of the vertical structure of the mineral dust microphysical properties and offers complementary information to that from column-integrated variables retrieved from passive remote sensing. Additionally, lidar depolarization profiles and LIRIC retrieved volume concentration are compared with aircraft in situ measurements. This study presents for the first time a comparison of the total volume concentration retrieved with LIRIC with independent in situ measurements, obtaining agreement within the estimated uncertainties for both methods and quite good agreement for the vertical distribution of the aerosol layers. Regarding the depolarization, the first published data set of the CAS-POL for polarization ratios is presented here and qualitatively compared with the lidar technique.

\section{Introduction}

Mineral dust is estimated to be the most abundant aerosol type in the atmosphere ( $\sim$ half of the total global aerosol burden) (e.g., Textor et al., 2007; Choobari et al., 2014), with global emission between 1000 and $3000 \mathrm{Mt} \mathrm{yr}^{-1}$ (Zender et al., 2003, 2004; Shao et al., 2011). Mineral dust directly scatters and absorbs solar and infrared radiation (Miller and Tegen, 1998), and impacts the optical properties of clouds (Ferek et al., 2000; Rosenfeld et al., 2001; Creamen et al., 2013). In addition, mineral dust particles can act as cloud condensation and ice nuclei (Twohy et al., 2009; Ansmann et al., 2009a; DeMott and Prenni, 2010) and affect air quality (Fairlie et al., 2010). The high temporal and spatial variability of dust particles and the complexity in their microphysical and optical properties present a significant challenge to our understanding of how these particles impact the environment.

Numerous field campaigns have been conducted to better characterize mineral dust properties, e.g., the Saharan Mineral Dust Experiments SAMUM-1 and SAMUM-2 (Ansmann et al., 2009b, 2011a and references therein) and the Saharan Aerosol Long-range Transport and Aerosol-CloudInteraction Experiment SALTRACE (http://www.pa.op.dlr. de/saltrace/), among others. However, the information on mineral dust properties is still quite scarce (Formenti et al., 2011), even though many measurements worldwide have been made using different approaches. Satellites are providing global coverage but the retrievals of particle properties are still affected by large uncertainties (Levy et al., 2013). Moreover, the interaction of dust particles with solar and terrestrial radiation is complex due to their irregular shapes and variable refractive indices (Mishchenko et al., 1997). Because of this, in the past years it has been difficult to develop accurate algorithms for the retrieval of dust microphysical properties from optical measurements. Dubovik et al. (2006), one of the first studies that addressed this problem, developed an algorithm that took into account the scattering patterns of non-spherical particles and implemented an inversion method for column-integrated radiometric measurements in the AERONET (Aerosol Robotic Network) network (http://aeronet.gsfc.nasa.gov/, Holben et al., 1998). Other approximations using non-spherical models have also been proposed, e.g., Olmo et al. (2006), Valenzuela et al. (2012a). However, due to the inherent characteristics of the sun-photometer only daytime retrievals are possible. The linear estimation (LE) algorithm, introduced in Veselovskii et al. (2012), allows for the retrieval columnintegrated aerosol microphysical properties with high temporal resolution (Kazadzis et al., 2014) during both day and nighttime taking advantage of sun- and star-photometry measurements (Pérez-Ramírez et al., 2015).

Currently, information on the vertical distribution of the mineral dust can also be retrieved by different techniques. Information of mineral dust on the vertical coordinate is essential for understanding particle transport processes from regional to intercontinental scales, to improve radiative forcing calculations and to analyze the influence of mineral dust on cloud formation (Ansmann et al., 2008, 2009a, b, 2011a; Seifert et al., 2010). Therefore, advanced methods to characterize dust microphysical properties profiles from remote sensors like lidar systems are crucial. In this framework, Chaikovsky et al. (2012, 2015), developed the Lidar Radiometer Inversion Code (LIRIC) that can provide vertically resolved profiles of aerosol microphysical properties during daytime by combining elastic lidar measurements and column-integrated sun-photometer microphysical properties retrieved from AERONET. Even though multiwavelength lidar measurements are required at least in three wavelengths, the widespread use of multiwavelength elastic backscattered lidar systems in networks such as EARLINET (European Aerosol Research Lidar Network, Pappalardo et al., 2014) and LALINET (Latin American Lidar Network, GuerreroRascado et al., 2014) provides enough global coverage. The availability of collocated simultaneous AERONET measurements in most of these lidar stations widely expands the applicability of LIRIC.

As with the case of the column-integrated microphysical properties, LIRIC retrievals are also limited to daytime because of the use of the sun-photometer measurements. To overcome this difficulty, the regularization technique implemented by Veselovskii et al. (2010) can be used to retrieve nighttime aerosol microphysical profiles. The method by Veselovskii et al. (2010) implemented the kernel functions of Dubovik et al. (2006) in a regularization technique (Müller et al., 1999; Veselovskii et al., 2002) to obtain vertically resolved dust properties. This approach was first implemented using data of the SAMUM field campaign (Müller et al., 2013) and from measurements of long-range transport of dust over Europe (e.g., Veselovskii et al., 2010; Papayannis 
et al., 2012). This technique has the limitation that for the input data Raman or HSRL measurements are required. Because of the low signal-to-noise ratio in these systems, their use is mostly limited to nighttime. Additionally, acquiring and maintaining Raman and HSRL systems is quite costly. Hence, their implementation is not as widespread as elastic backscatter systems.

During the summer of 2011, a measurement campaign was launched at Granada experimental station during a dust event in order to contribute to better characterize mineral dust properties. One of the main goals of this campaign (previously presented in Bravo-Aranda et al., 2015) was to use the synergy between different remote sensing techniques to retrieve the evolution of microphysical properties of mineral dust during day and nighttime at different levels. Results obtained for both column-integrated and vertical profiles of mineral dust microphysical properties are presented in this study.

Measurements performed at Granada were coordinated with a flight of the CASA C-212-200 research aircraft above the station (Andrey et al., 2014; Bravo-Aranda et al., 2015) on 27 June 2011. The aircraft was equipped with in situ instrumentation that allowed us to compare for the first time, up to the best of our knowledge, the microphysical properties profiles retrieved with LIRIC with well-established simultaneous in situ measurements. On the other hand, the aircraft was equipped with a CAS-POL, which provided polarization information; this will be explained in detail later on. With the measurements acquired by this sonde, we were seeking to make for the very first time a qualitative comparison of an in situ measurement of depolarization ratio with that measured remotely by the lidar depolarization technique.

\section{Experimental site and instrumentation}

\subsection{Experimental site}

The data from ground-based instrumentation were acquired at the Andalusian Institute for Earth System Research (IISTA-CEAMA) located in the city of Granada $\left(37.16^{\circ} \mathrm{N}\right.$, $3.61^{\circ} \mathrm{W}, 680 \mathrm{~m}$ a.s.1.), (Lyamani et al., 2010; Titos et al., 2012; Valenzuela et al., 2012b). Granada is a mediumsize city in the southeast of Spain located in a natural basin, delimited on the east by mountains with peaks up to $3000 \mathrm{~m}$ a.s.l. Air masses affecting the area arrive mainly from the Atlantic Ocean, central Europe, the Mediterranean Basin and northern Africa (Valenzuela et al., 2012a; PérezRamÍrez et al., 2012a). The number of mineral dust events at the Granada station originating in northern Africa is quite high, especially during summer, with an occurrence of $45 \%$ of the days in June, July, and August (Valenzuela et al., 2012b). These events can transport particles at altitudes of up to $5500 \mathrm{~m}$ a.s.l., not always affecting the surface level (Guerrero-Rascado et al., 2008, 2009; Navas-Guzmán et al., 2013). The experimental site is also impacted by anthro- pogenic particles from local and regional aerosol sources (Lyamani et al., 2008, 2010, 2012; Titos et al., 2014).

\subsection{Ground-based instrumentation}

\subsubsection{Lidar system MULHACEN}

The Raman-lidar MULHACEN (based on LR331D400, Raymetrics, Greece) used for aerosol vertical-profiling is described in detail by Guerrero-Rascado et al. $(2008,2009)$ and Navas-Guzmán et al. (2011). It employs a Nd:YAG laser that emits at three different wavelengths $(355,532$, and $1064 \mathrm{~nm})$. The receiving system consists of detectors that split the radiation according to the three elastic channels $(355,532$, and $1064 \mathrm{~nm}$ ), two nitrogen Raman channels $(387,607 \mathrm{~nm})$ and a water vapor Raman channel $(408 \mathrm{~nm})$. These Raman measurements have sufficient signal-to-noise ratio only for nighttime detection. The system also measures depolarization of the returned signal at $532 \mathrm{~nm}$ (532-cross and 532parallel detection channels) (Bravo-Aranda et al., 2013) for retrieving vertical profiles of the particle linear depolarization ratio $\left(\delta_{\lambda}^{\mathrm{P}}\right)$. The aerosol optical properties profiles presented in this study were obtained by means of the KlettFernald (Fernald et al., 1972; Fernald, 1984; Klett, 1981) algorithm during daytime and using the Raman technique (Ansmann et al., 1990) at night. The depolarization profiles were retrieved according to the methodology described in Bravo-Aranda et al. (2013) and Freudentaler et al. (2009). More details on the retrieval of the aerosol optical properties profiles from the lidar data presented in this study can be found in Bravo-Aranda et al. (2015). The estimated uncertainties associated with the lidar signals are between \pm 15 and $20 \%$ for the aerosol particle backscatter coefficient, $\beta_{\lambda}^{\text {aer }}$, and $\pm 20 \%$ for the aerosol particle extinction coefficient, $\alpha_{\lambda}^{\text {aer }}$. These estimates are based on the statistical uncertainties retrieved with Monte Carlo techniques according to Pappalardo et al. (2004) and Guerrero-Rascado et al. (2008). The procedure described by Wandinger and Ansmann et al. (2002) to correct the incomplete overlap of the system is applied to our data. The use of this overlap correction allows us to obtain reliable $\beta_{\lambda}^{\text {aer }}$ profiles at 355 and $532 \mathrm{~nm}$ down to $320 \mathrm{~m}$ above the station (Navas-Guzmán et al., 2011); however, reliable data are obtained only from $\sim 1000 \mathrm{~m}$ above the station for $\alpha_{\lambda}^{\text {aer }}$. The Raman lidar system is part of EARLINET and currently is included in the ACTRIS2 (Aerosols, Clouds, and Trace gases Research InfraStructure Network 2) European project (http://www.actris.net/).

\subsubsection{Sun-photometer CIMEL CE-318}

Sun photometric measurements obtained at Granada are used to obtain column-integrated aerosol properties using a CIMEL CE-318. This instrument is included in the AERONET-RIMA network (Iberian Network for Aerosol Measurements, federated to AERONET) since 2002 and 
is calibrated following the AERONET protocols. Details about the CIMEL sun-photometer can be found in Holben et al. (1998); however, a brief description is presented here. This instrument makes direct sun measurements at 340 , $380,440,500,670,870,940$, and $1020 \mathrm{~nm}$ and sky radiance measurements at $440,670,870$, and $1020 \mathrm{~nm}$. The direct sun measurements are used to retrieve aerosol optical depth $\left(\tau_{\lambda}\right)$ at $340,380,440,500,675,870$ and $1020 \mathrm{~nm}$. The $\tau_{\lambda}$ uncertainties provided by AERONET are \pm 0.02 for $\lambda<400 \mathrm{~nm}$ and \pm 0.01 for $\lambda>400 \mathrm{~nm}$. Additionally, the spectral dependency of the $\tau_{\lambda}$ has been considered through the Angström exponent, AE (440-870), calculated in the range $440-870 \mathrm{~nm}$. Also included in the analysis are aerosol optical depths at $500 \mathrm{~nm}$ for fine mode $\left(\tau_{\text {fine }}\right)$ and for coarse mode $\left(\tau_{\text {coarse }}\right)$ as well as the fine mode fraction $(\eta)$ (ratio of $\tau_{\text {fine }}$ to $\tau$ ), determined using the spectral de-convolution algorithm method developed by O'Neill et al. (2003). In addition, column-integrated aerosol microphysical properties (size distribution, refractive index, volume concentration, etc.) provided by the AERONET code are also used (Dubovik and King, 2000; Dubovik et al., 2002, 2006). For the retrieval of the aerosol microphysical properties both the direct sun and the sky radiance measurements are used. The reported size distribution retrieval uncertainties are \pm 10 $35 \%$, for the size range $0.1 \mu \mathrm{m}<r<7 \mu \mathrm{m}$, and outside this range they are as large as $\pm 80-100 \%$. All the data used here are Level 1.5 data obtained using the AERONET Version 2 algorithm. Only a small number AERONET Level 2.0 were available due to the restrictions imposed by AERONET code $\left(\tau_{440 \mathrm{~nm}}>0.4\right.$ and solar zenith angle $\left.>50^{\circ}\right)$. Therefore, AERONET Level 1.5 (cloud screened data with pre- and post-calibrations applied) were used in this study, considering only those data that fulfil the following conditions to assure their quality: $\tau_{440 \mathrm{~nm}}>0.2$ and solar zenith angle $>50^{\circ}$.

\subsubsection{Star-photometer EXCALIBUR}

EXCALIBUR provides $\tau_{\lambda}$ measurements from the stars' direct irradiance using interferential filters at 380, 436, 500, 670,880 , and $1020 \mathrm{~nm}$ (nominal wavelengths) using a CCD camera as detector during nighttime. More details can be found in Pérez-Ramírez et al. (2008a, b). A regular calibration of the instrument is performed once a year at a high mountain location. Errors in the $\tau_{\lambda}$ are \pm 0.02 for $\lambda<800 \mathrm{~nm}$ and \pm 0.01 for $\lambda>800 \mathrm{~nm}$ (Pérez-Ramírez et al., 2011). Data are cloud-screened and quality assured over $30 \mathrm{~min}$ intervals (Pérez-Ramírez et al., 2012b).

\subsubsection{Aerodynamic Particle Sizer APS-3321}

Auxiliary measurements of the particle size distribution and concentration at the surface were performed with an aerodynamic particle sizer (APS-3321; TSI). This instrument is an optical particle counter that measures particle diameter and aerosol concentration, in real time, in 52 nominal size bins in the aerodynamic diameter range $0.50-20 \mu \mathrm{m}$ by determining the time-of-flight of individual particles in an accelerating flow field. The APS can measure concentrations up to 1000 particles $\mathrm{cm}^{-3}$ at 0.5 and $10 \mu \mathrm{m}$, with coincidence errors inferior to 5 and $10 \%$, respectively. The minimum and maximum concentrations that can be measured are 0.001 and 10000 particles $\mathrm{cm}^{-3}$, respectively. For solid particles, counting efficiencies range from 85 to $99 \%$ (Volckens and Peters, 2005). The APS was operated at flow rate of $5 \mathrm{~L} \mathrm{~min}^{-1}$ and with data averaging time of $5 \mathrm{~min}$.

Air sampling for APS instrument was obtained from the top of a stainless steel tube, $20 \mathrm{~cm}$ diameter and $5 \mathrm{~m}$ length (Lyamani et al., 2008). The inlet was located about $15 \mathrm{~m}$ above the ground surface. The measurements were performed without aerosol size cut-off and no heating was applied to the sampled air.

\subsection{Aircraft in situ instrumentation}

Meteorological and aerosol particle measurements were made with instruments mounted on the CASA C-212-200 research aircraft, operated by the Spanish National Institute of Aerospace Technology (INTA). Details on aircraft measurements can be found in Andrey et al. (2014) and BravoAranda et al. (2015). Here we give a short overview of the instruments used for our study: the Cloud and Aerosol Spectrometer with Polarization detection (CAS-POL) and the the Passive Cavity Aerosol Spectrometer (PCASP-100X).

The CAS-POL measures the light scattered by individual particles passing through a focused, $658 \mathrm{~nm}$ polarized laser beam (Baumgardner et al., 2001). The equivalent optical diameter (EOD), over a nominal size range from 0.6 to $50 \mu \mathrm{m}$, is derived from the light that is collected over a $4-12^{\circ}$ solid angle in the forward direction, assuming that the particle is spherical with a refractive index of 1.54-i0.0 (McConnell et al., 2010). The backscattered light is collected over the solid angle $168-176^{\circ}$ and then separated with a beam splitter into two components. One component is directed to a detector with a polarized filter to transmit only scattered light that is perpendicular to the plane of polarization of the incident light. This component is referred to as the " $S$ " polarization. The other component is directed to a detector with no filter so it measures the total backscattered light. In order to get the backscattered light that is polarized in the same plane as the incident light, the parallel " $P$ " polarization, the signal from the " $S$ " polarization detector is subtracted from the total backscattering detector.

The size derivation is well calibrated, using reference particles of polystyrene latex spheres (PSL) and glass beads (crown glass and boric acid) of monodispersed size and known refractive index at the wavelength of the CAS-POL. The total backscatter signals are also related to particle size with the same reference particles.

For the depolarization data, there are currently no reference particles that produce a known intensity of polarized 
scattered light. Hence, the " $S$ " and derived " $P$ " signals are presently used only qualitatively and the depolarization ratio, defined as the quotient " $S$ " to " $P$ ", cannot be quantitatively compared with the same ratio derived from the lidar measurements. The procedure for setting the gains of the " $S$ " and " $P$ " detectors is explained in greater detail in Appendix A. As will be amplified in the following sections, the CAS-POL depolarization ratios will be compared with those from the lidar vertical profiles in a qualitative way to evaluate the performance and potential of the in situ depolarization measurements with the CAS-POL, not absolute values are evaluated.

The measurement uncertainties are associated with the accuracy of determining the sample volume and the derivation of the EOD. The estimated uncertainty in the sample volume is $\pm 20 \%$ and the sizing uncertainty ranges from 20 to $50 \%$ depending on the variation in the refractive index and the non-sphericity of the particles. The degree of non-sphericity and the orientation of the particle in the beam leads to variations of the depolarization ratio of $20-100 \%$, depending on the aspect ratio of the dust (see Appendix A and Fig. 9 for more detail).

The errors in the sample volume and size are propagated using the root sum squared (RSS) approach to estimate the uncertainty in the derived bulk parameters of number and volume concentrations and the median volume diameter. These estimated uncertainties are $\pm 20, \pm 90$ and $\pm 50 \%$, respectively. A detailed description of the CAS-POL and associated uncertainties is given in Appendix A.

The other instrument on the aircraft that measured aerosol size distributions was the Passive Cavity Aerosol Spectrometer (PCASP-100X) that provides aerosol size distributions in the $0.1-3 \mu \mathrm{m}$ diameter range in 15 different bins. The measurements from the PCASP increased the size range provided by the CAS-POL measurements down to $0.1 \mu \mathrm{m}$ in our study. The measurement principle and uncertainties $(20 \%$ for the size distributions) have been described in detail by $\mathrm{Cai}$ et al. (2013), Rosenberg et al. (2012) and references therein.

\section{Methodology: retrievals of aerosol particles microphysical properties}

\subsection{LIRIC code}

The LIRIC algorithm is applied to lidar and sun-photometer data to retrieve aerosol particle microphysical properties profiles during daytime (Chaikovsky et al., 2008, 2012, 2015; Wagner et al., 2013; Granados-Muñoz et al., 2014, 2015; Binietoglou et al., 2015). This algorithm requires the column-integrated optical and microphysical properties retrieved from AERONET code as input data (Dubovik et al., 2002; Dubovik et al., 2006) and measured lidar elastic backscattered signals at least at three different wavelengths $(355,532$, and $1064 \mathrm{~nm})$. The depolarization information from lidar data can optionally be used in LIRIC.
To perform the retrieval, an aerosol model, based on the AERONET code, which assumes a mixture of randomly oriented spheroid and spherical particles defined by the column-integrated volume concentrations of each mode, is used (Dubovik and King, 2000; Dubovik et al., 2006). Subsequently, an iterative procedure based on the LevenbergMarquardt method is applied. The combined lidar and sunphotometer information provides volume concentration profiles for the fine and coarse modes, distinguishing also between coarse spherical and coarse spheroid particles if depolarization information is considered. The separation between the fine and the coarse modes is made by searching the radius located at the minimum of the AERONET bimodal size distribution in the radii range between 0.194 and $0.576 \mu \mathrm{m}$. Uncertainties of the volume concentration profiles related to the different user-defined parameters used within LIRIC algorithm are usually below 15\% (Granados-Muñoz et al., 2014), proving LIRIC to be quite stable. A detailed analysis on the uncertainty due to the input lidar and sun-photometer data uncertainties is still lacking, but it can be estimated for our case. The uncertainty in the retrieved volume concentration is related to the size distribution that is retrieved from AERONET. As discussed above, this uncertainty can range from 10 to $35 \%$ if the particle radii are less than $7 \mu \mathrm{m}$ but can be as much as $100 \%$ if there is significant volume in particles larger than this (Dubovik et al., 2000). As will be illustrated below, measurements of the volume-size distribution with the CAS-POL show that there are particles larger than $7 \mu \mathrm{m}$ radius and in the dust layer they can be larger than $30 \mu \mathrm{m}$. Hence, a reasonable estimate of the retrieved volume uncertainty in our case is approximately $50 \%$, less than the $90 \%$ uncertainty estimated for the volume measured by the CAS-POL (Appendix A).

\subsection{Inversion of Raman lidar measurements to retrieve microphysical properties}

The Raman lidar system provides $\alpha_{\lambda}^{\text {aer }}$ profiles at 355 and $532 \mathrm{~nm}, \beta_{\lambda}^{\text {aer }}$ at $355,532,1064 \mathrm{~nm}$ and the $\delta_{\lambda}^{\mathrm{P}}$ at $532 \mathrm{~nm}$. This $3 \beta+2 \alpha+1 \delta$ data set was inverted to retrieve the aerosol particle microphysical properties using the regularization approach, described in detail by Müller et al. (1999) and Veselovskii et al. (2002, 2004).

To account for mineral dust particles non-sphericity the model of randomly oriented spheroids was used, as described in Veselovskii et al. (2010). Following this approach, the minimum and maximum particle size are determined during the retrieval. A large number of inversion windows are tested by using the look up tables introduced in Veselovskii et al. (2010), which comprise radii between 0.05 and $25 \mu \mathrm{m}$. The real and imaginary part of the refractive indices are varied in the range $1.45-1.55$ for the real part and $5 \times 10^{-4}-$ 0.01 for the imaginary part. The particle volume concentration and effective radius in our case were estimated with an uncertainty of about 50 and $25 \%$, respectively. The real part 


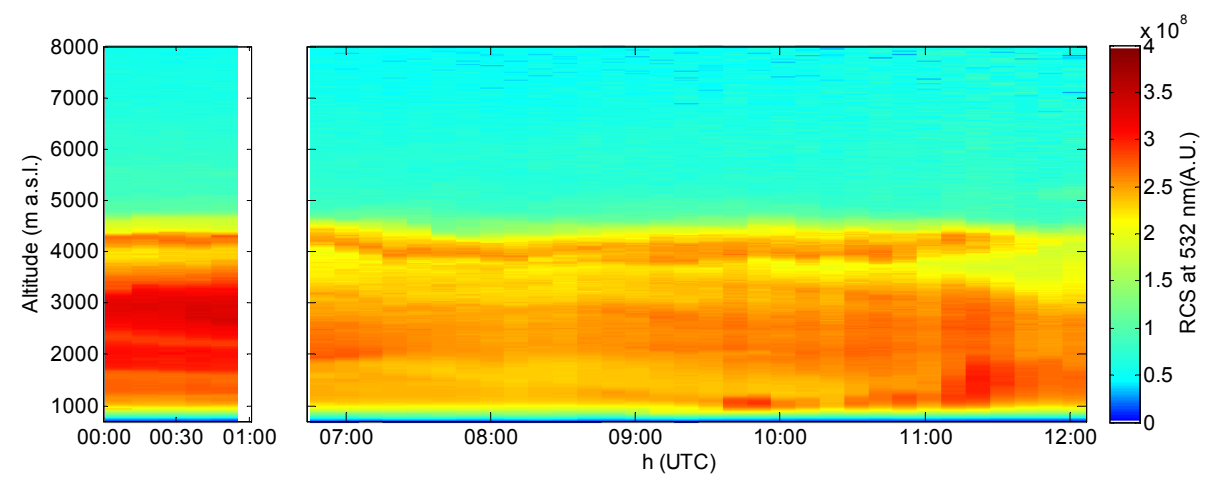

Figure 1. Time series of the RCS for the period 00:00-01:00 and 06:45-12:10 UTC on the 27 June 2011.

of the refractive index, $m_{\mathrm{r}}$, was also estimated, with an uncertainty of \pm 0.05 . A detailed description on the procedure to calculate the uncertainties is included in Veselovskii et al. (2010).

\subsection{Inversion of $\tau_{\lambda}$ spectral measurements}

In the present study, we used two different techniques to retrieve the column-integrated aerosol microphysical properties. Firstly, data provided by AERONET operational algorithm (version 2) were used to retrieve the aerosol microphysics during daytime by inversion of $\tau_{\lambda}$ and sky radiances obtained from the sun-photometer. In addition to these AERONET aerosol retrievals, we inverted $\tau_{\lambda}$ spectral values with the LE algorithm to get high temporally resolved aerosol properties such as the integrated volume and effective radius (Kazadzis et al., 2014). The LE algorithm is described in Veselovskii et al. (2012) and more details are provided by Pérez-Ramírez et al. (2015), where correction functions to get accurate aerosol data close to that of the operational AERONET code were introduced. The LE algorithm is applied in our study to both sun- and star-photometer data, allowing us to retrieve column-integrated aerosol microphysical properties during day and night.

\section{Results and discussion}

Different models such as NAAPS (Navy Aerosol Analysis and Prediction System) (Christensen, 1997) and BSCDREAM8b (Pérez et al., 2006a, b; Basart et al., 2012), forecast mineral dust above Granada station on the 27 June 2011. Based on these forecasts, a measurement campaign was launched using all the available instrumentation at the IISTACEAMA experimental station coordinated with a simultaneous flight of the CASA C-212-200 research aircraft (BravoAranda et al., 2015). The flight took place around 10:30 UTC on 27 June, whereas ground-based measurements started the night before to cover the dust event during night and daytime (Fig. 1). The aircraft performed a pseudo spiral track flying from 1200 to $5200 \mathrm{~m}$ a.s.l. at a distance of approximately $8 \mathrm{~km}$ from the IISTA-CEAMA station.

\subsection{Column-integrated aerosol microphysical properties}

Columnar aerosol optical and microphysical properties from the sun and star photometry measurements are shown in Fig. 2. Figure 2a illustrates the temporal trends in the $\tau_{500 \mathrm{~nm}}$, and the corresponding contributions of fine $\left(\tau_{\text {fine }}\right)$ and coarse $\left(\tau_{\text {coarse }}\right)$ modes using the Spectral Deconvolution Algorithm (O'Neill et al., 2001a, b; 2003). The $\tau_{\lambda}$-related Ångström exponent $\left(\operatorname{AE}\left(\lambda_{1}-\lambda_{2}\right)\right)$ computed using the wavelengths between 440 and $870 \mathrm{~nm}$ (436 and $880 \mathrm{~nm}$ for star photometry) and the fine mode fraction $(\eta)$ are shown in Fig. 2b. As can be observed, there was a smooth temporal evolution of the aerosol properties with small variations. $\tau_{500 \mathrm{~nm}}$ time series indicated that the aerosol load slightly varied during the analyzed period, with values ranging between 0.27 and 0.37 . $\tau_{\text {coarse }}$ was significantly larger than $\tau_{\text {fine }}$ during the end of the night and daytime measurements, whereas $\tau_{\text {fine }}$ was almost constant around 0.1 during the study period. The simultaneous increase of $\tau_{500 \mathrm{~nm}}$ and $\tau_{\text {coarse }}$ from midnight suggests an increase of the incoming mineral dust in the atmospheric column. However, during the first hours of the night, the fine mode had a relevant contribution to the total $\tau_{500 \mathrm{~nm}}$. The AE ranged between 0.80 at nighttime and 0.4 during daytime, suggesting a clear predominance of coarse particles that can be associated with the transport of dust particles. However, the larger values obtained at the beginning of the night period are higher than those acquired from AERONET measurements in the presence of mineral dust (e.g., Dubovik et al., 2002), and thus the contribution of fine particles to the aerosol mixture is also considerable.

The evolution of the effective radius, $r_{\text {eff }}$, and the column volume concentration, $V$, obtained both by LE and AERONET retrievals during daytime and by LE during nighttime for the 27 June 2011 is shown in Figs. 2c and 2d. Good agreement between AERONET and LE retrievals was obtained during daytime corroborating the good perfor- 

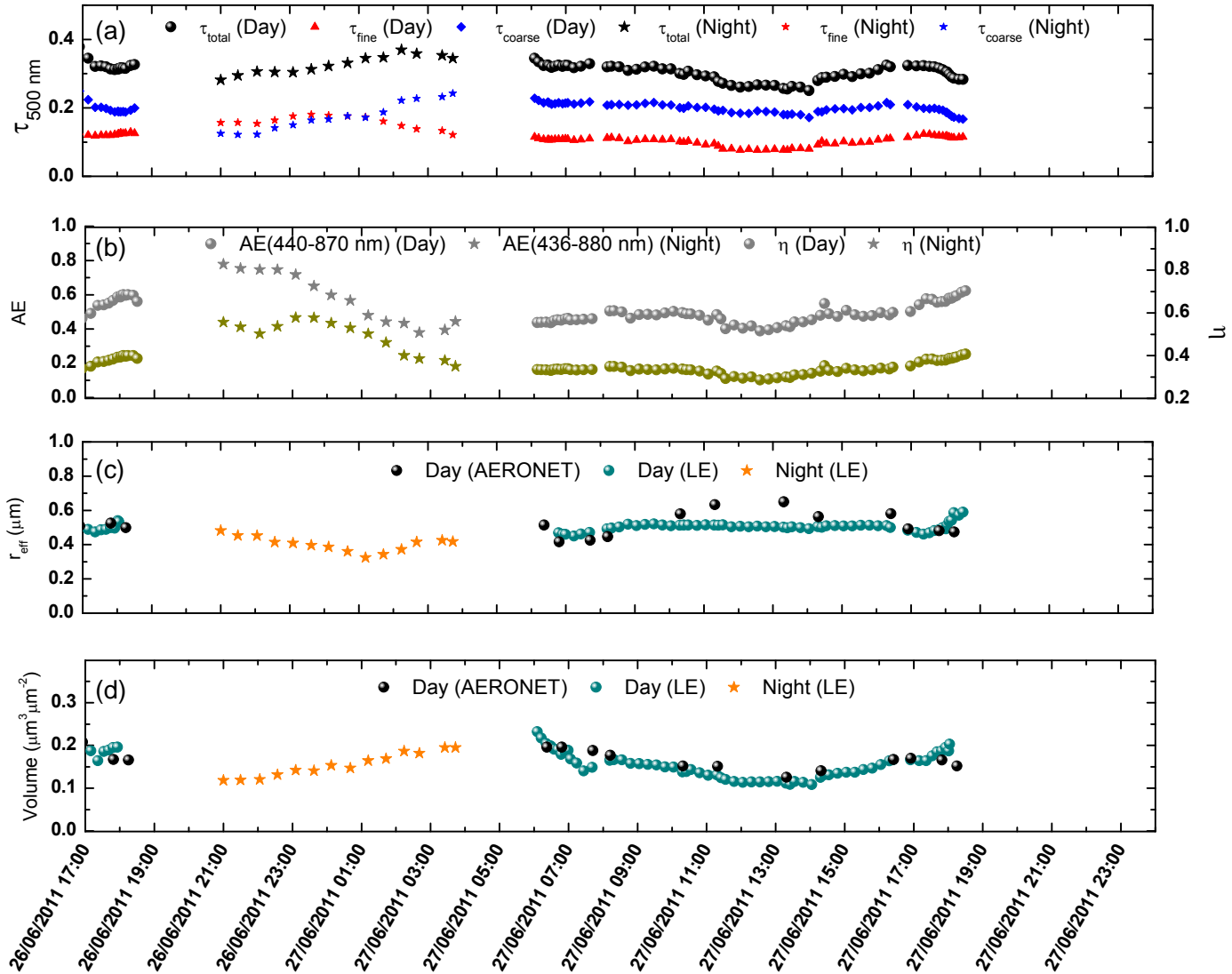

Figure 2. Night-to-day temporal evolution of (a) aerosol optical depth $\left(\tau_{\lambda}\right)$ including also its separation between fine ( $\left.\tau_{\text {fine }}\right)$ and coarse ( $\left.\tau_{\text {coarse }}\right)$ mode at $500 \mathrm{~nm}$, (b) Ångström exponent (AE) between 440 and $870 \mathrm{~nm}$ (436-880 nm for star photometry) and fine mode fraction $\eta$ (c) effective radius $\left(r_{\text {eff }}\right)$ and (d) column-integrated volume concentration $(\mathrm{V})$ on 27 June 2011.

mance of the LE method. In addition, continuity between the star- and sun-photometer measurements was observed, which shows the utility of combining both instruments to perform a continuous monitoring of aerosol properties. As observed in Figs. 2c-d, both $r_{\text {eff }}$ and $V$ were slightly lower during the night compared to daytime. The $r_{\text {eff }}$ values were around $0.3-$ $0.4 \mu \mathrm{m}$ during nighttime and almost constant around $0.5 \mu \mathrm{m}$ during daytime. These values suggest a predominance of coarse particles in the atmospheric column. The $V$ values were increasing from $0.15 \mu^{3} \mu \mathrm{m}^{-2}$ during the night up to $0.25 \mu \mathrm{m}^{3} \mu \mathrm{m}^{-2}$ in the early morning and then they decreased again down to $0.1 \mu \mathrm{m}^{3} \mu \mathrm{m}^{-2}$ at noon. The changes observed in aerosol properties suggest a mixture of different aerosol types changing from night to day.

\subsection{Mineral dust microphysical properties profiles}

\subsubsection{Daytime retrieval of mineral dust microphysical properties profiles with LIRIC}

A comprehensive analysis of the optical properties profiles retrieved during daytime by Klett-Fernald (Fernald et al., 1972; Fernald, 1984; Klett, 1981) method and during night- time by Raman method (Ansmann et al., 1990) was previously presented by Bravo-Aranda et al. (2015) and is out of the scope of our study. However, some of the optical profiles (Fig. 3) and a brief discussion are included here to contextualize the mineral dust event in a way that we have enough information to properly discuss and understand the evolution of the microphysical properties profiles.

Figure 3 shows $\beta_{532 \mathrm{~nm}}^{\text {aer }}, \beta-\mathrm{AE}(355-532 \mathrm{~nm})$, which is the backscatter related Angström exponent between 355 and $532 \mathrm{~nm}$ and $\delta_{532 \mathrm{~nm}}^{\mathrm{P}}$, obtained during daytime from lidar elastic measurements. According to this figure and BravoAranda et al. (2015) two different layers were clearly distinguished. The first layer was in the height range between 3000 and $5000 \mathrm{~m}$ a.s.l., where $\beta_{532 \mathrm{~nm}}^{\text {aer }}$ values were decreasing during the morning and $\beta-\mathrm{AE}(355-532 \mathrm{~nm})$ profiles suggest the predominance of coarse particles with values close to zero during the analyzed period. $\delta_{532 \mathrm{~nm}}^{\mathrm{P}}$ values ranged between 0.23 and 0.28 , suggesting an important contribution of non-spherical particles (Gross et al., 2011). However, below $2000 \mathrm{~m}$ a.s.l., $\beta-\mathrm{AE}(355-532 \mathrm{~nm})$ was decreasing from 2 in the early morning down to $\sim 0.5$ around midday. At the same time, $\delta_{532 \mathrm{~nm}}^{\mathrm{P}}$ was increasing from 0.08 up to 0.20 , suggest- 


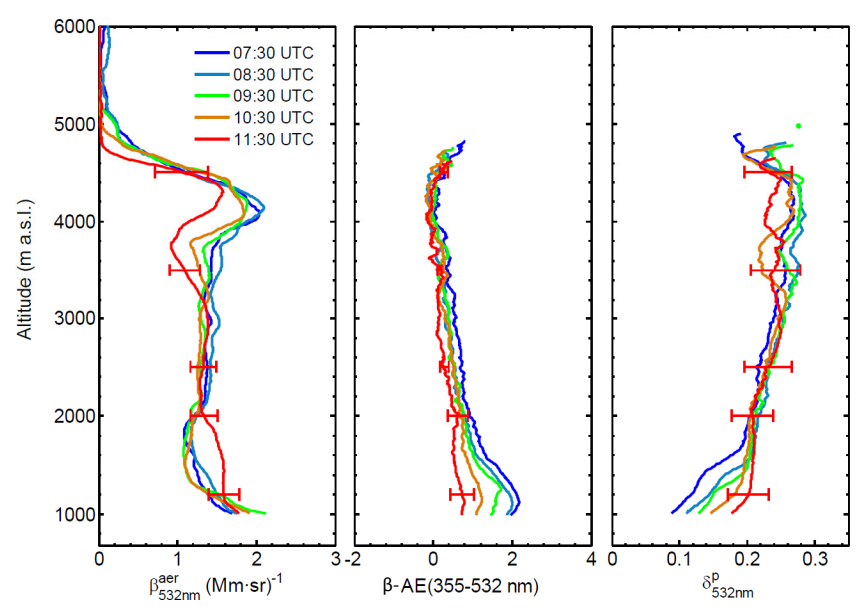

Figure 3. Profiles of (a) aerosol particle backscatter at $532 \mathrm{~nm}$ $\left(\beta_{532 \mathrm{~nm}}^{\text {aer }}\right)$ (b) backscatter-related Ångström exponent between 355 and $532 \mathrm{~nm}(\beta-\mathrm{AE}(355-532 \mathrm{~nm}))$ and (c) linear particle depolarization ratio at $532 \mathrm{~nm}\left(\delta_{532 \mathrm{~nm}}^{\mathrm{P}}\right)$ retrieved from lidar elastic measurements at different hours between 07:30 and 11:30 UTC on the morning of the 27 June 2011.

ing the influence of anthropogenic particles from local origin that were mixed with the mineral dust due to convective processes within the planetary mixing layer (Bravo-Aranda et al., 2015).

LIRIC retrievals obtained for the morning of the 27 June 2011 are shown in Fig. 4. A clear predominance of the coarse spheroid mode is observed from the surface up to $5000 \mathrm{~m}$ a.s.l., as expected for mineral dust events. In addition, a decrease of the total volume concentration values occurred throughout the morning, as expected from the observed decrease in $\beta_{532 \mathrm{~nm}}^{\text {aer }}$ (Fig. 3) and the decrease in the integrated volume concentration $V$ (Fig. 2d). A maximum peak in the volume concentration of the coarse spheroid mode was observed between 4000 and $4500 \mathrm{~m}$ a.s.l., in coincidence with the maximum in $\beta_{532 \mathrm{~nm}}^{\mathrm{aer}}$ profiles, indicating the presence of a distinguished aerosol layer at this height. It is worth noting that fine particles were also observed during the different analysis periods as indicated by the volume concentration profiles, but in low concentrations $\left(\sim 6 \mu \mathrm{m}^{3} \mathrm{~cm}^{-3}\right)$. The fact that the profiles of the fine mode volume concentration show a maximum peak at the same height as the coarse spheroid mode suggests that these fine particles could have been advected with the mineral dust. Therefore, they might correspond to the fine mode of mineral dust (Mamouri and Ansmann, 2014) or even anthropogenic aerosol advected from the industrial areas of northern Africa together with the mineral dust (Rodríguez et al., 2011; Valenzuela et al., 2012c), as indicated by the backward trajectories analysis performed with HYSPLIT model using GDAS meteorological database (http://ready.arl.noaa.gov/HYSPLIT_traj.php, not shown). However, Granados-Muñoz et al. (2014) suggested that it might be an artifact introduced by LIRIC due to problems with the incomplete overlap or in cases of nonhomogeneous layering distributing the contribution of local pollution at high altitudes. Additional data sets would be required to clarify the origin of these fine particles in our study.

The coarse spherical mode volume concentration slightly increased during the morning, reaching its maximum values $\left(\sim 7 \mu \mathrm{m}^{3} \mathrm{~cm}^{-3}\right)$ between 11:15 and 11:45 UTC. This slight increase in the volume concentration of the coarse spherical mode (from 0 up to $5 \mu \mathrm{m}^{3} \mathrm{~cm}^{-3}$ ) around $4500 \mathrm{~m}$ a.s.l. was in agreement with a slight decrease in $\delta_{532 \mathrm{~nm}}^{\mathrm{P}}$ values (from 0.28 to 0.23 ) in the same height range, indicating a larger contribution of spherical particles and corroborating once again the coherence between the aerosol optical and microphysical properties profiles obtained.

Even though layering was observed in the optical properties profiles (Fig. 3), with mineral dust in the upper layer between 3000 and $5000 \mathrm{~m}$ a.s.l. and anthropogenic particles in the lower part of the troposphere, LIRIC results showed much more homogeneous profiles with no such layering. The layering observed in the optical properties profiles (Fig. 3) indicated the presence of mineral dust in the upper layer between 3000 and $5000 \mathrm{~m}$ a.s.l. and the presence of anthropogenic particles in the lower part of the troposphere that was not detected by LIRIC. This can be explained by the fact that LIRIC assumes several AERONET-retrieved properties (i. e., refractive index, size distribution, sphericity, etc.) as heightindependent and therefore LIRIC results are much more vertically homogeneous regarding the distribution of the modes than those retrieved from the lidar data with Klett-Fernald algorithm. A combined inversion of lidar and sun-photometer data without such assumptions, as the one proposed in GARRLIC (Generalized Aerosol Retrieval from Radiometer and Lidar Combined data) (Lopatin et al., 2013), might provide more accurate results regarding the vertical distribution of the aerosol properties, although GARRLIC is out of the scope of this work. Meanwhile, the interpretation and analysis of the LIRIC-retrieved volume concentration profiles needs to be carefully made when the atmospheric aerosol layers comprise different aerosol types, as shown in Granados-Muñoz et al. (2014).

\subsubsection{Nighttime retrieval of mineral dust microphysical properties profiles with the regularization technique}

Figure 5 shows the aerosol optical and microphysical properties profiles retrieved for the first period of lidar measurements (00:00-01:00 UTC). The Raman $3 \beta+2 \alpha+\delta$ profiles (Figs. 5a, b and c) were inverted to retrieve vertical profiles of volume concentration, $r_{\text {eff }}$ and the real part of the refractive index (Fig. 5d and e) using the regularization approach by Veselovskii et al. (2010).

During the night period, values of $\beta_{532 \mathrm{~nm}}^{\text {aer }}$ (Fig. 5b) were similar to those observed at daytime (Fig. 3), especially in the early morning (06:15-06:45 UTC). Two differentiated re- 


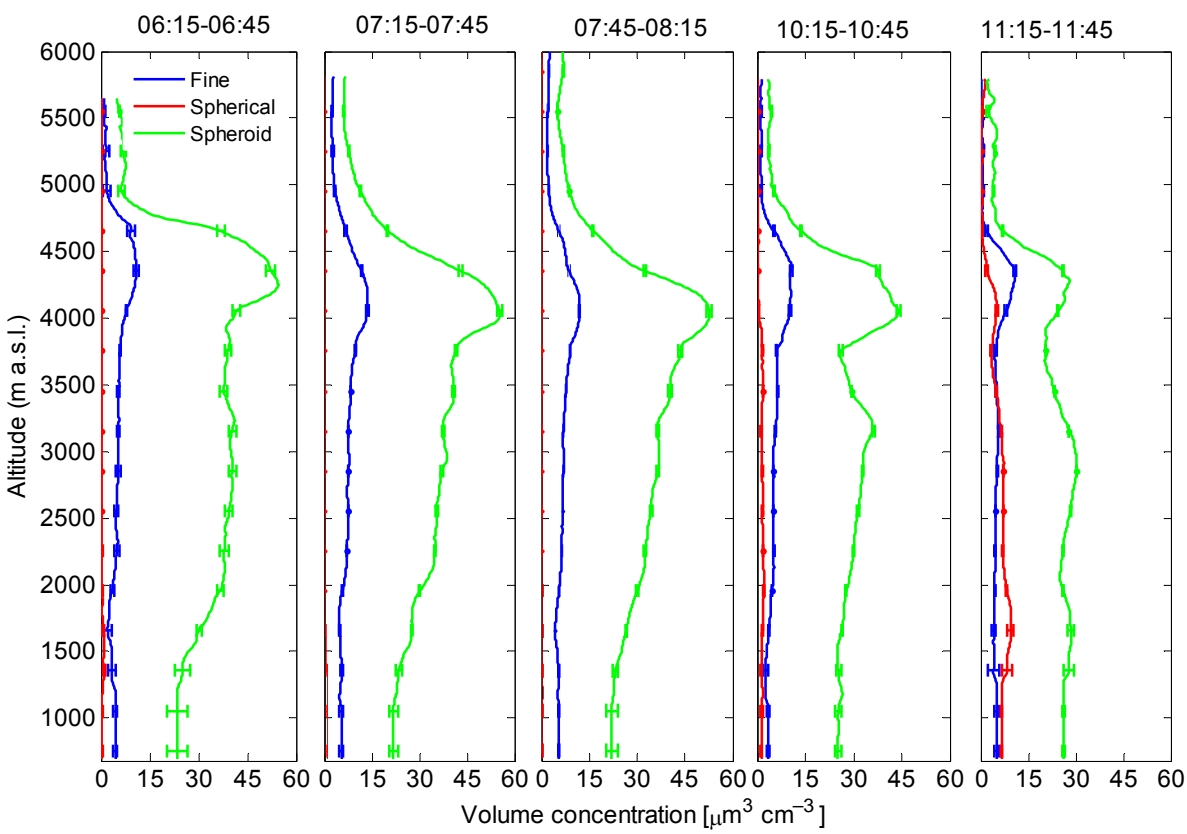

Figure 4. Volume concentration profiles of the fine, coarse spherical and coarse spheroid modes obtained with LIRIC from 30 min averaged lidar data for different periods on the 27 June 2011. The error bars represent the uncertainty associated to the selection of the user-defined input parameters in LIRIC, obtained as indicated in Granados-Muñoz et al. (2014).

Table 1. Aerosol properties on region 1, corresponding to the mixture of anthropogenic aerosol and mineral dust below $2250 \mathrm{~m}$ a.s.1. and region 2, corresponding to the mineral dust particles located above $2250 \mathrm{~m}$ a.s.l.

\begin{tabular}{lrrrrr}
\hline & $\beta_{532 \mathrm{~nm}}^{\text {aer }}\left(\mathrm{Mm}^{-1} \mathrm{sr}^{-1}\right)$ & $\delta_{532 \mathrm{~nm}}^{\mathrm{P}}$ & $\beta-\mathrm{AE}(355-532 \mathrm{~nm})$ & $r_{\text {eff }}(\mu \mathrm{m})$ & $\mathrm{V}\left(\mu \mathrm{m}^{3} \mathrm{~cm}^{-3}\right)$ \\
\hline Region 1 & 38 & 0.15 & 0.18 & 0.61 & 44 \\
Region 2 & 82 & 0.25 & 0.05 & 1.23 & 54 \\
\hline
\end{tabular}

gions with different aerosol types were observed at night. Namely, there were mineral dust particles above $2250 \mathrm{~m}$ a.s.l. $\left(\delta_{532 \mathrm{~nm}}^{\mathrm{P}} \sim 0.25\right)$ and a mixing of local anthropogenic aerosol with mineral dust below this height. Even though, similar layers were observed during both analyzed periods, the vertical structure of the aerosol layer was different, indicating an evolution of the aerosol vertical structure during the night. As observed when comparing Figs. 5 and 3, two peaks were detected during nighttime around 3200 and $4200 \mathrm{~m}$ a.s.l. whereas a more homogeneous structure was observed during daytime, with only one maximum at $4100 \mathrm{~m}$ a.s.l. Besides, a significant increase of the anthropogenic pollution in the lower layer was observed during the morning.

Mineral dust microphysical properties profiles were obtained with the regularization technique using the optical data, averaged in $250 \mathrm{~m}$ layers for the heights between 2000 and $3600 \mathrm{~m}$ a.s.l. Above that height averaging was done in $1000 \mathrm{~m}$ layers. The overlap effects prevented using extinction data below $2000 \mathrm{~m}$ and therefore inversion of microphysical properties was not possible below this height. The retrieved profiles are shown in Fig. 5d, 5e and 5f. As we can observe in
Fig. $5 \mathrm{~d}, r_{\text {eff }}$ values varied in the different layers. The highest values, $\sim 1.76 \mu \mathrm{m}$, were found in the layer between 2500 and $3500 \mathrm{~m}$ a.s.l., which is the mineral dust layer. The smallest values, $\sim 0.53 \mu \mathrm{m}$, were found in the layer where the anthropogenic pollution was mixed with the mineral dust, below $2300 \mathrm{~m}$ a.s.l. layer . Values around $4200 \mathrm{~m}$ a.s.l. $(\sim 1.1 \mu \mathrm{m})$ were still larger than those in the lower layer, but lower than in the maximum around $3200 \mathrm{~m}$ a.s.l. This decrease in the radius with height can be due to an artifact of the algorithm because of the larger averaging height interval used in the upper part of the profiles and not necessarily related to a decrease in the size of the particles. Volume concentration values were also larger for the dust layer than for the one with mixed particles. This fact can be explained by both the volume concentration dependence on particle radius and also the larger aerosol load in this layer (as observed in the layering structure of $\beta_{\lambda}^{\text {aer }}$ in Fig. 5b). Two regions were also clearly distinguished in the $m_{\mathrm{r}}$ profile obtained with the regularization technique. The $m_{\mathrm{r}}$ values were larger in the upper part of the profile, corresponding to the mineral dust layer and lower values were obtained in the lower part of the profile, 

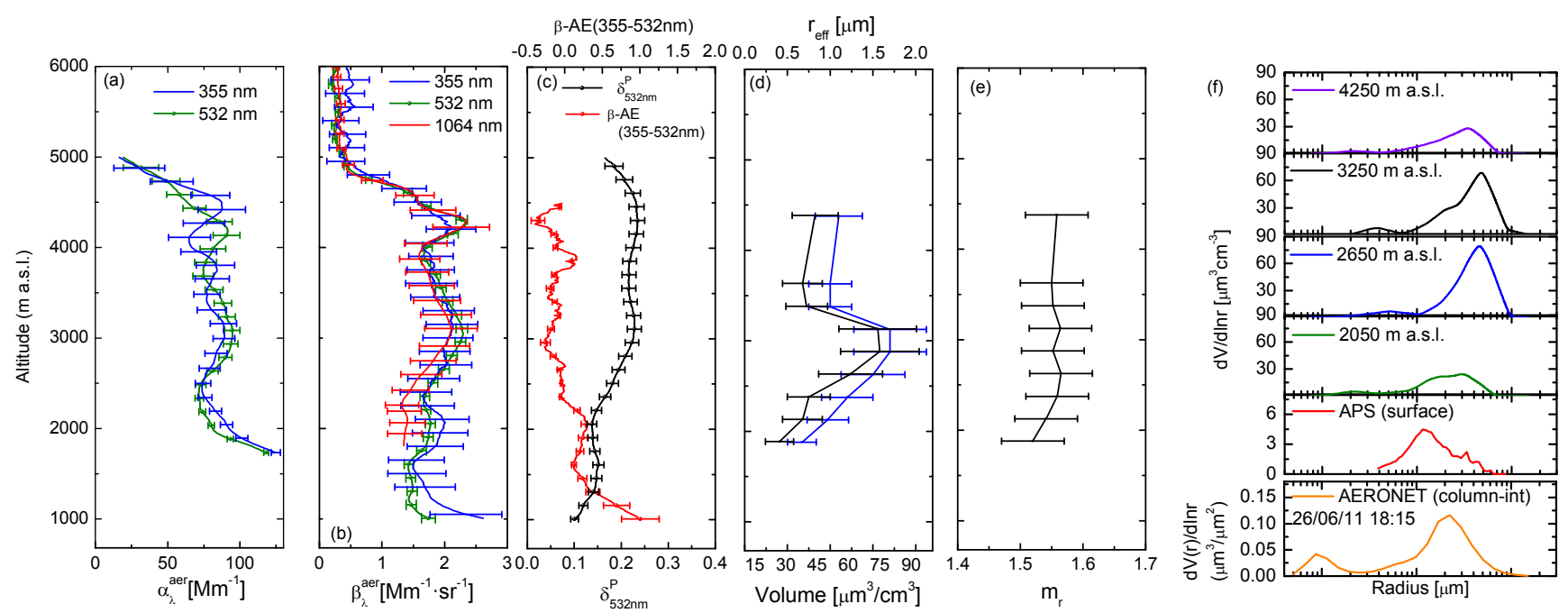

Figure 5. (a) $\beta_{532 \mathrm{~nm}}^{\mathrm{aer}}$ and $\alpha_{532 \mathrm{~nm}}^{\mathrm{aer}}$ retrieved with Raman technique and (b) derived $\beta-\mathrm{AE}(355-532 \mathrm{~nm})$ and $\delta_{532 \mathrm{~nm}}^{\mathrm{P}}$ at 00:00-01:00 UTC on the 27 June 2011. (c) Total volume concentration, $r_{\text {eff }}$ and (d) $m_{\mathrm{r}}$ retrieved for the same period with the regularization technique applied to the $3 \beta+2 \alpha+1 \delta$ lidar data and (e) Volume-size distributions retrieved at different height levels using the APS (surface level) and the regularization technique applied to the $3 \beta+2 \alpha+1 \delta$ lidar data at 00:00-01:00 UTC on the 27 June 2011. Column-integrated AERONET size distribution corresponding to the 26 June 2011 at 18:15 UTC is included (bottom).

due to the presence of the mixture of mineral dust and anthropogenic particles. The mean value of $m_{\mathrm{r}}$ in the profile was $1.55 \pm 0.05$. A summary with the values of the different aerosol properties in both detected layers is shown in Table 1.

Finally, Fig. $5 \mathrm{f}$ shows the volume-size distributions for different altitudes. At the surface level, the APS was used to obtain the hourly average volume-size distribution in the aerodynamic radius range $0.25-10 \mu \mathrm{m}$ for the period 00:00 to 01:00. The volume-size distributions at higher altitudes were obtained by the regularization technique. In addition, the closer-in-time column-integrated AERONET size distribution (26 June 2011 at 18:15 UTC) was included for comparison. From both APS and lidar measurements, it was observed a clear increase in the coarse mode radius with height, as the location of the maximum is displaced towards larger radii, in agreement with $r_{\text {eff }}$ profiles. There was also an increase of the aerosol load since the maximum in the volume concentration strongly increased with height. Fine mode was almost insignificant in the different layers. However, the AERONET column-integrated distribution showed a small contribution of the fine mode aerosol particles and also the coarse mode radius shifted to smaller values. The low column-integrated values of $r_{\text {eff }}$ obtained with the LE algorithm in Fig. 2 together with the AERONET distribution suggest an important contribution of fine particles in the region below $2 \mathrm{~km}$ a.s.l. during the analyzed period, not observed by the lidar because of the incomplete overlap. This contribution of fine particles also explains the difference in the real part of the refractive index between the closest in time AERONET retrieval, which was 1.45 , and the value obtained with the regularization technique (1.55). The limitations of the APS to measure fine mode particles at the surface do not allow to confirm this, but in situ measurements presented by Bravo-Aranda et al. (2015) also pointed in this direction.

\subsection{Comparison of airborne in situ measurements and ground-based retrieved profiles}

\subsubsection{Comparison of the volume concentration profiles}

Figure 6a shows the vertical profiles of the total volume concentration profiles obtained with LIRIC algorithm and those obtained from the aircraft in situ measurements. The horizontal bars on the LIRIC profile (blue curve) are the estimated uncertainties of $\pm 50 \%$. The horizontal bars on the aircraft profile (black curve) are the standard deviation about the mean value. For the retrieval of the volume concentration profiles from the in situ aircraft measurements, a refractive index of 1.54-i0.0 (McConnell et al., 2010) was assumed and Mie theory was applied assuming spherical aerosol particles as explained by Andrey et al. (2014) and discussed in Appendix A. This refractive index value is very similar to the one obtained with the regularization technique for the nighttime measurements, which was $1.55 \pm 0.05$. Therefore, the assumption of the refractive index is not expected to introduce large uncertainties. The agreement in the vertical structure between the aircraft and LIRIC volume concentration profiles, with respect to where the peak values are located, is quite good considering that the aircraft profiles are horizontally displaced from those by the lidar by approximately $8 \mathrm{~km}$. Similar layering was detected with both LIRIC and the airborne data, distinguishing two maximum peaks around 3500 and $4200 \mathrm{~km}$ a.s.l. The geometrical thickness of the dif- 

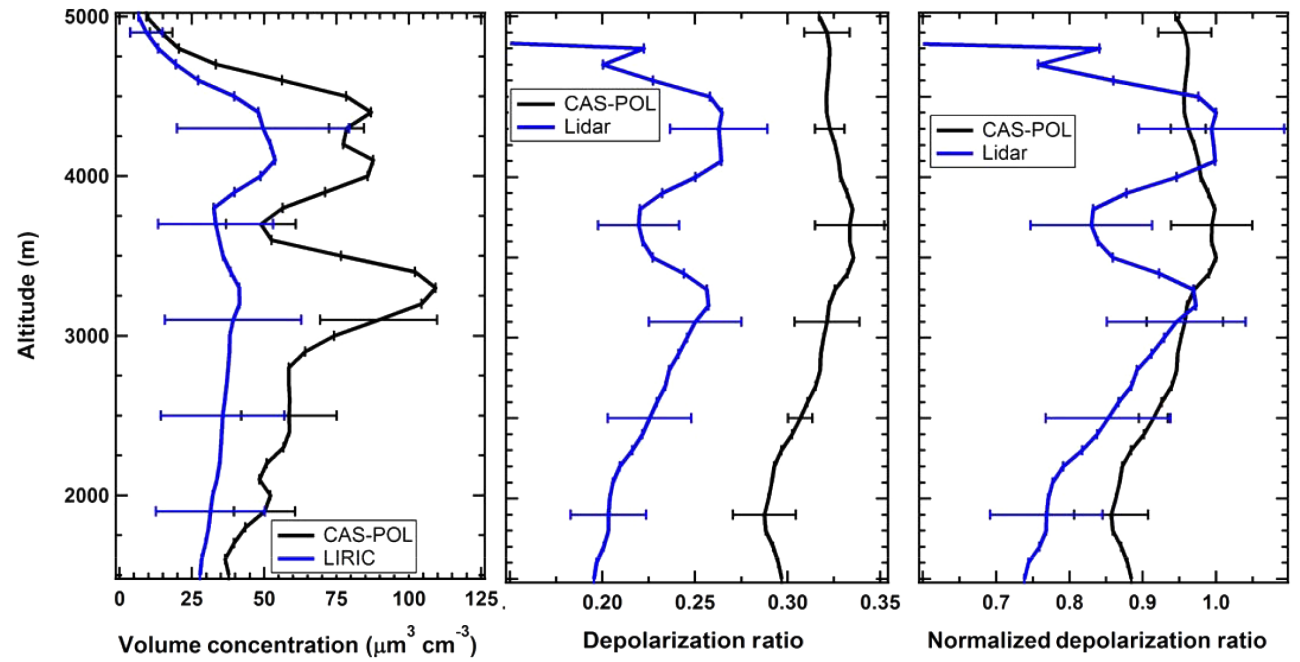

Figure 6. (a) $30 \mathrm{~min}$ averaged volume concentrations retrieved with LIRIC (blue line) centered at 10:30 UTC and the combined PCASP$100 \mathrm{X}$ and CAS-POL concentrations (black line) retrieved during the flight ascent on the 27 June 2011. The blue horizontal bars are the estimated uncertainty in the LIRIC values and the black horizontal bars are the standard deviation about the average aircraft values. (b) Depolarization ratio retrieved from the CAS-POL measurements (black line) and $\delta_{532 \mathrm{~nm}}^{\mathrm{P}}$ retrieved from the lidar data (blue line) between 10:30 and 11:00 UTC Horizontal bars show the estimated uncertainties from the lidar (blue) and the standard deviation about the average CAS-POL values (black). (c) Depolarization ratios normalized to the maximum values derived from the lidar (blue) and CAS-POL (black).

ferent layers observed was also very similar for both LIRIC and the aircraft data. The slight difference between the height of the first maximum obtained by aircraft in situ measurements (3450 $\mathrm{m}$ a.s.1.) and LIRIC algorithm (3250 $\mathrm{m}$ a.s.1.) can easily be explained by taking into account the differences between both techniques and the horizontal distance between the lidar and the aircraft measurements.

Regarding the volume concentration values, the differences are within the expected uncertainties and natural variability, marked by the horizontal bars in Fig. 6a, revealing quite promising results. In general, average in situ values exceed those from LIRIC by less than $20 \mu^{3} \mathrm{~cm}^{-3}$, except for the concentration maximum between 3200 and $3500 \mathrm{~m}$ a.s.l. The difference between the profiles reveals a likely underestimation of the volume concentration profiles retrieved by LIRIC by some fraction that depends on the amount of particle volume in sizes larger than $15 \mu \mathrm{m}$ (in radius) not considered in AERONET. However, this underestimation does not completely explain the observed differences. The intrinsic differences between both techniques and the differences in sampling can also lead to discrepancies between the profiles. This comparison analysis raises the question as to which technique is providing the more accurate value. Both techniques rely on assumptions that could potentially bias the results. In the discussion of the CAS-POL uncertainties in Appendix A, the two most important assumptions are related to the refractive index and shape of the particles. If the refractive index of the particles differ from what is assumed, this can bias the sizing either smaller or larger, but no more than $20 \%$. The assumption that the particles are spherical will bias the sizes, and hence the volumes, perhaps even as much as a factor of 2 if the dust particles are very aspherical. This could explain the discrepancies between the two techniques over most of the profiles where the differences are within a factor of 2. Countering that argument, however, is the comparison of the size distributions measured with the combined PCASP-100X and the CAS-POL and those derived from the regularization technique applied to nighttime lidar measurements. Figure 7 shows average volume concentration size distributions, measured with the PCASP and CAS-POL at 3250 and $4250 \mathrm{~m}$, the altitudes of maximum particle concentrations. Also shown are the size distributions derived from the lidar measurements using the regularization method. The in situ and remote sensing derived spectra show very similar shapes; i.e., the maximum peaks at $3250 \mathrm{~m}$ fall at $4 \mu \mathrm{m}$ and $3.5 \mu \mathrm{m}$, respectively for the CAS-POL and lidar and at 4 and $5 \mu \mathrm{m}$ at $4250 \mathrm{~m}$. It was suggested earlier that the larger volume concentrations measured by the CAS-POL might be a result of oversizing but Fig. 7 indicates that this is not the case.

\subsubsection{Comparison of the depolarization ratio profiles}

A number of airborne particle depolarization ratios measurements with lidar have been made in the past (e.g., Weinzierl et al., 2009) and compared with ground based lidar; however, in situ measurements of particle polarization ratios from aircraft have never been published before, so the results presented here are the first opportunity to compare profiles from aircraft with those derived from remote sensors and analyze the potential of aircraft depolarization measurements. 


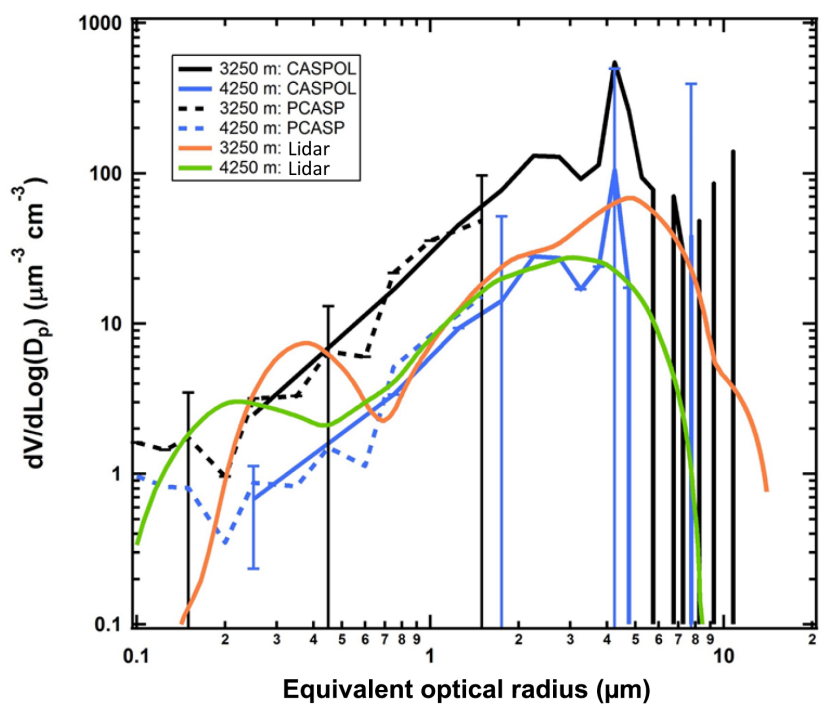

Figure 7. Size distributions of volume concentrations derived from the combined PCAP-100X and CAS-POL measurements and size distributions retrieved with the regularization technique from the lidar nighttime measurements at 3250 and $4250 \mathrm{~m}$.

The CAS-POL averaged polarization ratio at a wavelength of $658 \mathrm{~nm}$ is compared with the $\delta_{532 \mathrm{~nm}}^{\mathrm{P}}$ profile retrieved at 10:30 UTC from the lidar data (Fig. 6b). The horizontal bars on the lidar profile (blue curve) show the estimated uncertainties, while the bars on the CAS-POL values (black curve) are the standard deviations about the average. The polarization ratios from the CAS-POL are calculated as the summed perpendicular-polarization values divided by the summed parallel-polarization values in order to be more comparable with the ensemble averages provided by the lidar. In general, we observe a rough agreement in the vertical distribution of the depolarization derived from lidar $\delta_{532 \mathrm{nn}}^{\mathrm{P}}$ profiles and CAS-POL, with a correlation coefficient between both profiles of 0.69. Note that, as discussed in greater detail in the Appendix, the CAS-POL measures the polarization components at a different angle than the $180^{\circ}$ measured by the lidar. This difference can lead to different polarization values. There are also few studies that quantitatively relate the polarization ratio to specific types of aspherical particles (in the Appendix, Fig. 9 we show laboratory studies that show polarization ratios measured by the CAS-POL for different particle types). From laboratory studies, water droplets produce an average polarization ratio of 0.18 for the CAS-POL (see Appendix), whereas this value is close to zero for lidar measurements. In Fig. 6b, the CAS-POL polarization ratio is offset by approximately this much; however, further studies are needed to better quantify the relationship between lidar and CAS-POL derived ratio.

In this study, we are more interested in comparing if both techniques show similar, relative changes in the depolarization ratio with altitude. In Fig. $6 \mathrm{c}$ we have normalized the depolarization ratios at each level by their maximum ratios, 0.26 and 0.34 for the lidar and CAS-POL techniques, respectively. Both methods are able to clearly distinguish between the dust layer in the upper part and the mixed dust with anthropogenic pollution in the lower part of the profiles. Some discrepancies are still observed in the lower layer of the profiles and in the region around $4.75 \mathrm{~km}$, but to explain them it is worthwhile to consider the different vertical resolution and that the CAS-POL is measuring instantaneous values, whereas the lidar data correspond to 30 -min averaged profiles. Taking into account the large variability observed in these regions throughout the morning in Fig. 3, the separation in time and location and the depolarization uncertainties for both data sets, differences are within the expected uncertainties. According to these results, calibrated profiles provided by the CAS-POL using laboratory measurements will provide valuable information on the aerosol vertical structure regarding depolarization. Depolarization information retrieved from aircraft measurements is currently very limited, and the use of the CAS-POL offers promising results in this respect for the near future.

\section{Summary}

An exhaustive measurement campaign was performed 27 June 2011 at Granada station during a Saharan dust outbreak. One of the main goals of the campaign was to analyze the evolution of mineral dust microphysical properties by using the synergy of different techniques. The campaign was coordinated with an aircraft research flight to be able to perform some comparisons based on completely independent data sets.

The different methods used for the retrieval of the microphysical properties were LIRIC and the regularization method, to retrieve vertical profiles with lidar data during both day and nighttime, and the AERONET code and the LE technique, to retrieve column-integrated properties from sunand star-photometry. To our knowledge this is the first time that these techniques are processed and compared together to retrieve continuous microphysical properties for day and night during a mineral dust event.

Results indicate that the night-to-day evolution of the aerosol optical depth at $500 \mathrm{~nm}$ and the Ångström exponent retrieved using star and sun-photometer data followed a smooth behavior explained by the natural variability of the aerosol particle population. The aerosol optical depth at $500 \mathrm{~nm}$ ranged between 0.27 and 0.37 during the analysis period, while the Ångström exponent varied from 0.80 at nighttime to 0.4 during the daytime. Column-integrated microphysical properties retrieved with the operational AERONET and linear estimation codes were in good agreement. Moreover, the linear estimation allowed for the retrieval of the dust microphysical properties during nighttime using the starphotometer data, which was not possible with the AERONET 

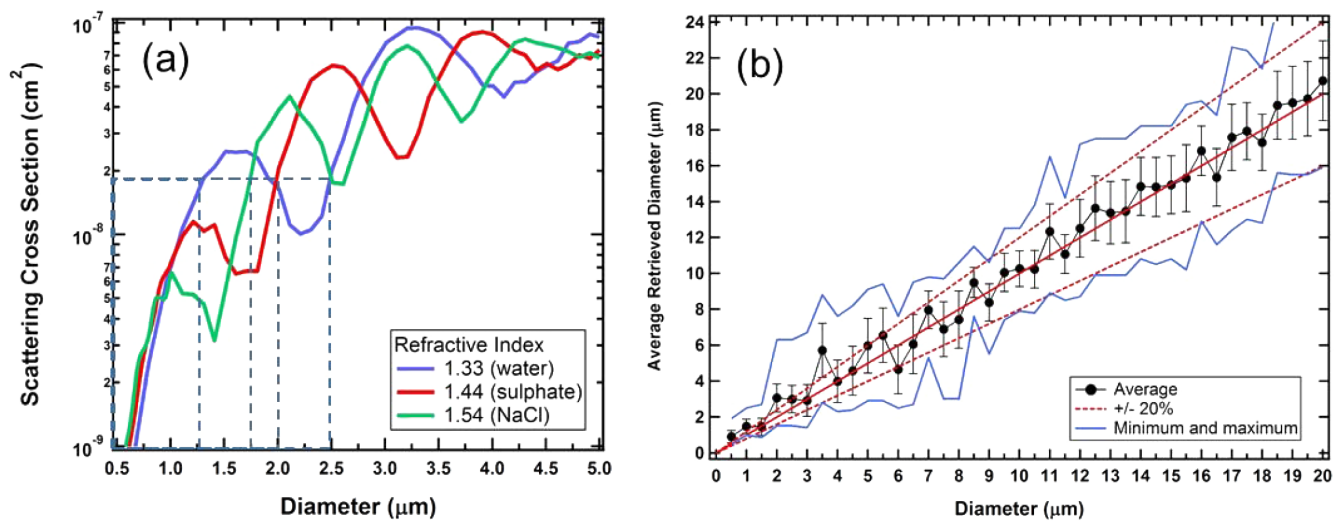

Figure 8. (a) Theoretical scattering cross section (Mie, 1908) of spherical particles as a function of diameter for three refractive indices and the collection angles of the CAS-POL. Only a small size range is shown in order to illustrate the potential magnitude of uncertainty. The dashed lines show that particles with four different sizes have the same scattering cross section. (b) Average retrieved diameter for a given size at a refractive index of 1.48. Vertical bars represent 1 standard deviation around the mean. The red lines are the one-to-one (solid) and $\pm 20 \%$ (dotted) around the one to one. Blue lines correspond to maximum and minimum errors for each diameter.

code. A smooth temporal evolution was observed, with effective radius ranging between 0.3 and $0.5 \mu \mathrm{m}$. The derived Ångström exponent and effective radius suggest a predominance of coarse particles but with some contribution by the fine mode particles. The fine contribution was quite significant during some periods, especially during the night period between 00:00 and 01:00 UTC. For this period, lidar measurements were performed, and combined vertical and column-integrated information revealed that most of the aerosol fine load was located below $2 \mathrm{~km}$ a.s.l., not affecting the mineral dust layer.

In the vertical coordinate, two aerosol layers were observed during both day and night: a lower layer corresponding to a mixture of anthropogenic aerosol with mineral dust and a higher layer corresponding to pure mineral dust. As expected in the presence of mineral dust, the LIRIC analysis during daytime indicated a clear predominance of the coarse spheroid mode, with average volume concentrations around $30 \mu \mathrm{m}^{3} \mathrm{~cm}^{-3}$, suggesting a medium intensity dust event. Fine particles were observed in lower concentrations $\left(\sim 6 \mu \mathrm{m}^{3} \mathrm{~cm}^{-3}\right)$ at higher altitudes that could be associated to particles of anthropogenic origin, along with the dust particles, in the industrial areas in the north of Africa or they might correspond to the mineral dust fine mode. However, they could also be related to a LIRIC artifact that distributes the local anthropogenic aerosol at higher altitudes. Results obtained with LIRIC are in agreement with the results obtained from the analysis of the optical properties retrieved from the lidar data in the upper layer corresponding to mineral dust. However, there is some disagreement in the lowermost part of the profiles, below $2000 \mathrm{~m}$ a.s.l., which corresponds to the mixture of mineral dust with anthropogenic aerosol. These discrepancies are mainly related to the assumption of height-independent aerosol properties in LIRIC

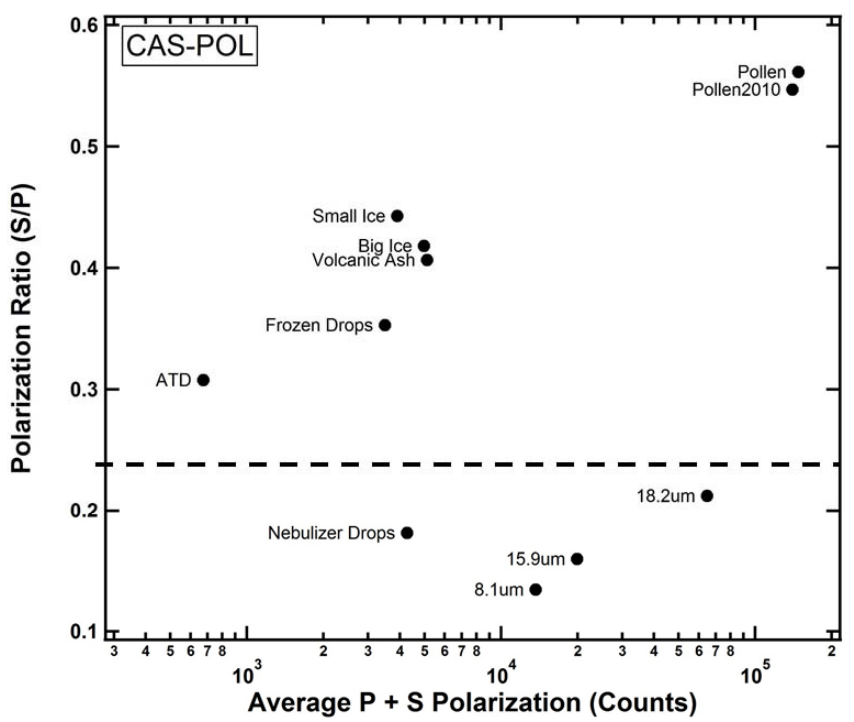

Figure 9. The average depolarization ratio as a function of the total backscattering ( $S$ plus $P$ polarization) derived from CAS-POL measurements in the laboratory of a number of different types of particles: calibration particles, labeled by their nominal size, nebulized water droplets, Arizona Test Dust (ATD), volcanic ash, ice crystals and pollen.

and indicate that LIRIC profiles need to be carefully interpreted in cases of non-homogeneous aerosol layers.

The retrieval of the total volume concentration profile at night (with the regularization technique) indicated a decrease in the volume concentration from maximum values of 75 to $50 \mu^{3} \mathrm{~cm}^{-3}$ and changes in the aerosol vertical structure when compared to LIRIC retrieved volume concentration profiles in the early morning. Nonetheless, columnintegrated values showed small changes in the aerosol prop- 
erties, remaining almost constant during the night. These results underscore the need for vertically resolved measurements to adequately monitor the evolution of the aerosol properties. The discrepancies between regularization and LIRIC results are mainly explained by the natural variability of the aerosol during the night. Because of this temporal variability, results obtained from the two different approaches are not comparable in absolute terms. However, from our analysis we can conclude that the combined use of LIRIC and the regularization technique improves our capability for evaluating the evolution of microphysical properties profiles during night and daytime.

For a direct intercomparison of LIRIC with the regularization technique, more simultaneous data sets are required. Advances in vibrational Raman will allow measurement of the extinction coefficients during the daytime (e.g., Brocard et al., 2013) and measurements from HSRL systems could also help in this aspect. On the other hand, advances in techniques to retrieve microphysical properties from star photometry will allow for the use of LIRIC during night. Improvements in the application of the linear estimation method also could be addressed in this way. Such approaches are essential both to study the temporal evolution of aerosol microphysical profiles and also to define strategies for evaluating satellite products.

In the last part of the study, profiles of linear particle depolarization retrieved with the lidar data and volume concentration retrieved with LIRIC were compared with in situ aircraft measurements. The vertical profiles of the volume concentration, retrieved from the combined PCASP-100X and CASPOL size distributions and LIRIC retrievals showed good agreement regarding the vertical distribution of the aerosol, with maxima at $3200-3500$ and $4100-4400 \mathrm{~m}$ identified by both techniques. The agreement between the volume concentration values were within the expected uncertainties with differences generally $<20 \mu \mathrm{m}^{3} \mathrm{~cm}^{-3}$. Although the comparison suggests that the volume concentrations from the CASPOL might be overestimated due to the asphericity of the dust particles, the size distributions derived from the CASPOL and lidar are in very good agreement.
The first-ever published data set of depolarization data retrieve with the CAS-POL instrument on board a research aircraft was also presented in this study and qualitatively compared with the lidar retrieved depolarization profiles. The two separate techniques showed roughly comparable results with respect to the depolarization ratios in the dust layer compared to the layers below and above.

\section{Conclusions and future outlook}

The synergy of instruments and different remote-sensing techniques presented in this study reveals the current existing potential to obtain a complete characterization of the aerosol properties using a combination of different measurements obtaining promising results. However, the comparison between the different ground-based remote sensing techniques and with independent aircraft in situ data also points out limitations of the different approaches used here and the need for reducing the uncertainty of the measured and retrieved aerosol properties in order to obtain more reliable and accurate aerosol properties databases. Future efforts should aim in this direction and validation campaigns and studies using independent data sets are crucial to achieve this goal. 


\section{Appendix A: CAS-POL measurement principles and uncertainties}

The CAS-POL in this study measures the light that is scattered by individual particles that pass through a focused, $658 \mathrm{~nm}$, polarized laser beam (Baumgardner et al., 2001). Optical components are positioned to collect some of the light that is scattered into a forward cone from 4 to $12^{\circ}$ and a backward cone from 168 to $176^{\circ}$. The backward scattered light is divided into two components: one that is measured with a detector that is behind an optical filter that passes only the scattered light with polarization that is perpendicular to the polarization of the incident light and another detector with no filter (Glen and Brooks, 2013). The equivalent optical diameter (EOD) of each particle in the nominal size range from 0.6 to $50 \mu \mathrm{m}$ is derived from the peak intensity of the collected forward scattered light using Mie theory (Mie, 1908) and an assumption of particle sphericity at a known refractive index. The terminology, EOD, is used here to underscore that ambient aerosol particles are only spherical if they are liquid or have a liquid coating and the refractive index can vary over a wide range. Hence, the EOD refers to the size of a spherical particle with known refractive index that would have scattered the equivalent intensity of light.

The three signals, forward scattering (FS), backward scattering (BS) and polarized (POL) provide three pieces of information that, from a relative perspective, can differentiate regions of air masses that have different particle characteristics. For the current study, FS is used to derive the EOD, and $\mathrm{BS}$ and POL are used to calculate the average polarization ratios discussed in the main body of the manuscript. The interaction of the linearly polarized laser radiation with a particle leads to scattered light with some of the polarization in the same plane as the incident light and some fraction at a perpendicular plane (Nicolet et al., 2007, 2010, 2012; Schnaiter et al., 2012; Baumgardner et al., 2014). In laboratory studies, Glen and Brooks (2013) showed that the relationships between the FS, BS, and POL signals were related to the type of dust; i.e., hematite, quartz, and zeolite could be clearly differentiated by comparing the three signals. In the analysis of CAS-POL measurements in the current study, we will only report the polarization ratio (defined below).

The measurement uncertainties are associated with the accuracy of determining the sample volume, the derivation of the EOD and the depolarization ratio. The estimated uncertainty in the sample volume is $\pm 20 \%$ primarily due to the optical technique used to qualify particles within the beam (Baumgardner et al., 2001). The sizing uncertainty ranges from 20 to $50 \%$ and depends on the variation in the refractive index and the non-sphericity of the particles. Figure 8a shows the theoretical scattering cross section (Mie, 1908) of spherical particles as a function of diameter for three refractive indices and the collection angles of the CAS-POL. Only a small size range is shown in order to illustrate the potential magnitude of uncertainty. We can see that particles with different sizes have the same scattering cross section. The scattering intensity is directly proportional to the particle optical cross section; hence, when we measure scattering of this magnitude with the instrument, we do not know if the particle was a water droplet with $1.25,2.0$, or $2.5 \mu \mathrm{m}$ EOD, a salt particle $(\mathrm{NaCl})$ with a 1.75 or $2.5 \mu \mathrm{m}$ EOD or a sulfate particle (refractive index of 1.44) with an EOD of $2.5 \mu \mathrm{m}$. The average uncertainty due to deriving an EOD of unknown refractive index was estimated by analyzing the variation in size when assuming a particle had a refractive index of 1.48 then finding what particle size would have the same scattering cross section if it actually had a different refractive index. The calculation was carried out over a range of refractive indices from 1.33 (water) to 1.60 (some types of organics). Figure $8 \mathrm{~b}$ presents the results of this evaluation, where the ordinate is the average derived value for the given size at a refractive index of 1.48 and the vertical bars are 1 standard deviation around the mean. The red lines are the one-toone (solid) and $\pm 20 \%$ (dotted) around the one to one. From this figure we see that the uncertainty falls within $\pm 20 \%$ of the assumed values except for the EOD between 2 and $4 \mu \mathrm{m}$. Hence, the uncertainty due to the refractive index variations is on average $\pm 20 \%$.

The uncertainties that are related to the non-sphericity of a particle are more difficult to estimate since they are dependent on the complexity of the morphology, the degree of non-sphericity and the orientation of the particle when it passes through the beam. Borrmann et al. (2000) applied Tmatrix theory to estimate the amount of undersizing of prolate and oblate spheroids dependent on their aspect ratios and demonstrated that the Forward Scattering Spectrometer Probe (FSSP), the predecessor to the CAS, could undersize ice crystals as much as $50 \%$. Single particle light scattering probes like the FSSP and CAS measure the optical size of a particle. Converting this size to a physical volume requires an assumption of the shape, refractive index, and density of the particle. Given the complexity of the morphology of dust, it is beyond the scope of this paper to evaluate the relationship between light scattering and particle morphology in order to assess the uncertainty in sizing related to the properties of dust. Based on the simple analysis conducted by Borrmann et al. (2000), we use $\pm 50 \%$ as a conservative estimate for the uncertainty in sizing due to shape.

The errors in the sample volume and size are propagated using the root sum squared (RSS) approach to estimate the uncertainty in the derived bulk parameters of number and volume concentrations and the median volume diameter. These estimated uncertainties are $\pm 20, \pm 90$ and $\pm 50 \%$, respectively.

The change in polarization caused by a particle is also dependent on aspect ratio and orientation. Volten et al. (2001) measured the light scattering by Sahara dust particles, among others, at angles ranging from 5 to $173^{\circ}$. In the angle range of the CAS-POL the polarization ratio varied from 0.2 to 0.5 . Recent laboratory measurements were made with a CAS- 
POL, similar to the one used in the study reported here, of various spherical and aspherical particles. The results from those measurements are summarized in Fig. 9 where the average polarization ratio is shown as a function of the sum of the $S$ and $P$ polarization signals. The horizontal and vertical bars show the standard deviations about the average values. From these very preliminary results we can see that the polarization ratio can vary as much as a factor of 2 , or $100 \%$. As seen in the results of measurements in the dust layer (Fig. 6), the variation is much less than this.

The detectors that measure the backscattered light are calibrated with monodisperse polystyrene latex spheres and glass beads that are reference standards approved by the National Institute of Science and Technology (NIST). The response of the two detection systems are matched by repeating the calibration but interchanging the optics so that both detectors will provide the same signal to the same reference particle, thus ensuring that the polarization ratio is a true measure of the ratio of the two polarized components.
The polarization ratios that are measured from particles of unknown composition cannot be referenced to a standard calibration particle that produces a known polarization pattern and subsequent polarization ratio. The lidar community calibrates their sensors in a similar manner as is done with the CAS-POL; however, to our knowledge there has not been a method to reference lidar depolarization methods against a known reference particle other than water droplets. It is also important to note that unlike lidars that measure at $180^{\circ}$, and hence have a polarization ratio of nearly zero for water droplets, the CAS-POL measures a non-zero polarization (Fig. 9) because water droplets do change the polarization state at angles less than $180^{\circ}$. 
Acknowledgements. This work was supported by the Andalusia Regional Government through project P12-RNM-2409, by the Spanish Ministry of Economy and Competitiveness through project CGL2013-45410-R and by the European Union's Horizon 2020 research and innovation programme through project ACTRIS-2 (grant agreement No 654109). The authors thankfully acknowledge the FEDER program for the instrumentation used in this work. CIMEL Calibration was performed at the AERONET-EUROPE calibration center, supported by ACTRIS (European Union Seventh Framework Program (FP7/2007-2013) under grant agreement no. 262254. M. J. Granados-Muñoz was funded under grant AP2009-0552. The authors thankfully acknowledge the computer resources, technical expertise, and assistance provided by the Barcelona Supercomputing Center for the BSC-DREAM8b model dust data. The authors express gratitude to the NOAA Air Resources Laboratory for the HYSPLIT transport and dispersion model and those at the NRL-Monterey that helped in the development of the NAAPS model. We also express our gratitude to the developers of LIRIC algorithm and software. We also thank N. T. O'Neill for providing the Spectral Deconvolution Algorithm used in the star-photometer. Thanks are also due to INTA Aerial Platforms, a branch of the Spanish ICTS program, and the Spanish Air Force for their efforts in maintaining and operating the aircraft. We would like to thank Ping Yang of Texas A\&M University for providing the results of his simulations of light scattering from different types of ice crystals.

Edited by: A. Ansmann

\section{References}

Andrey, J., Cuevas, E., Parrondo, M. C., Alonso-Pérez, S., Redondas, A., and Gil-Ojeda, M.: Quantification of ozone reductions within the Saharan air layer through a 13-year climatologic analysis of ozone profiles, Atmos. Environ., 84, 28-34, 2014.

Ansmann, A., Riebesell, M., and Weitkamp, C.: Measurement of atmospheric aerosol extinction profiles with a Raman lidar, Opt. Lett., 15, 746-748, 1990.

Ansmann, A., Tesche, M., Althausen, D., Müller, D., Seifert, P., Freudenthaler, V., Heese, B., Wiegner, M., Pisani, G., and Knippertz, P.: Influence of Saharan dust on cloud glaciation in southern Morocco during the Saharan Mineral Dust Experiment, J. Geophys. Res.-Atmos., 113, D04210, doi:10.1029/2007JD008785, 2008.

Ansmann, A., Tesche, M., Knippertz, P., Bierwirth, E., Althausen, D., Müller, D., and Schulz, O.: Vertical profiling of convective dust plumes in southern Morocco during SAMUM, Tellus B, 61, 340-353, 2009a.

Ansmann, A., Tesche, M., Seifert, P., Althausen, D., Engelmann, R., Fruntke, J., Wandinger, U., Mattis, I., and Müller, D.: Evolution of the ice phase in tropical altocumulus: SAMUM lidar observations over Cape Verde, J. Geophys. Res.-Atmos., 114, D17208, doi:10.1029/2008JD011659, 2009b.

Ansmann, A., Petzold, A., Kandler, K., Tegen, I., Wendisch, M., Mueller, D., Weinzierl, B., Mueller, T., and Heintzenberg, J.: Saharan Mineral Dust Experiments SAMUM-1 and SAMUM-2: what have we learned?, Tellus B, 63, 403-429, 2011a.
Basart, S., Pérez, C., Nickovic, S., Cuevas, E., and Baldasano, J. M.: Development and evaluation of the BSCDREAM8B dust regional model over Northern Africa, the Mediterranean and the Middle East, Tellus B, 64, 18539, doi:10.3402/tellusb.v64i0.18539, 2012.

Baumgardner, D., Jonsson, H., Dawson, W., O'Connor, D., and Newton, R.: The cloud, aerosol and precipitation spectrometer (CAPS): A new instrument for cloud investigations, Atmos. Res., 59-60, 251-264, 2001.

Baumgardner, D., Newton, R., Krämer, M., Meyer, J., Beyer, A., Wendisch, M., and Vochezer, P.: The Cloud Particle Spectrometer with Polarization Detection (CPSPD): A next generation open-path cloud probe for distinguishing liquid cloud droplets from ice crystals, Atmos. Res., 142, 2-14, 2014.

Binietoglou, I., Basart, S., Alados-Arboledas, L., Amiridis, V., Argyrouli, A., Baars, H., Baldasano, J. M., Balis, D., Belegante, L., Bravo-Aranda, J. A., Burlizzi, P., Carrasco, V., Chaikovsky, A., Comerón, A., D’Amico, G., Filioglou, M., Granados-Muñoz, M. J., Guerrero-Rascado, J. L., Ilic, L., Kokkalis, P., Maurizi, A., Mona, L., Monti, F., Muñoz-Porcar, C., Nicolae, D., Papayannis, A., Pappalardo, G., Pejanovic, G., Pereira, S. N., Perrone, M. R., Pietruczuk, A., Posyniak, M., Rocadenbosch, F., Rodríguez-Gómez, A., Sicard, M., Siomos, N., Szkop, A., Terradellas, E., Tsekeri, A., Vukovic, A., Wandinger, U., and Wagner, J.: A methodology for investigating dust model performance using synergistic EARLINET/AERONET dust concentration retrievals, Atmos. Meas. Tech., 8, 3577-3600, doi:10.5194/amt-83577-2015, 2015.

Borrmann, S., Luo, B., and Mishchenko, M.: Application of the T-matrix method to the measurement of aspherical (ellipsoidal) particles with forward scattering optical particle counters, J. Aerosol Sci., 31, 789-799, 2000.

Bravo-Aranda, J. A., Navas-Guzmán, F., Guerrero-Rascado, J. L., Pérez-Ramírez, D., Granados-Muñoz, M. J., and AladosArboledas, L.: Analysis of lidar depolarization calibration procedure and application to the atmospheric aerosol characterization, Int. J. Remote Sens., 34, 3543-3560, 2013.

Bravo-Aranda, J. A., Titos, G., Granados-Muñoz, M.J., GuerreroRascado, J. L., Navas-Guzmán, F., Valenzuela, A., Lyamani, H., Olmo, F. J., Andrey, J., and Alados-Arboledas, L.: Study of mineral dust entrainment in the planetary boundary layer by lidar depolarization technique, Tellus B, 67, 26180, doi:10.3402/tellusb.v67.26180, 2015.

Brocard, E., Philipona, R., Haefele, A., Romanens, G., Mueller, A., Ruffieux, D., Simeonov, V., and Calpini, B.: Raman Lidar for Meteorological Observations, RALMO - Part 2: Validation of water vapor measurements, Atmos. Meas. Tech., 6, 1347-1358, doi:10.5194/amt-6-1347-2013, 2013.

Cai, Y., Snider, J. R., and Wechsler, P.: Calibration of the passive cavity aerosol spectrometer probe for airborne determination of the size distribution, Atmos. Meas. Tech., 6, 2349-2358, doi:10.5194/amt-6-2349-2013, 2013.

Chaikovsky, A., Dubovik, O., Goloub, P., Balashevich, N., Lopatsin, A., Karol, Y., Denisov, S., and Lapyonok, T.: Software package for the retrieval of aerosol microphysical properties in the vertical column using combined lidar/photometer data (test version), Tech. rep., Institute of Physics, National Academy of Sciences of Belarus, Minsk, Belarus, 2008. 
Chaikovsky, A., Dubovik, O., Goloub, P., Tanre, D., Pappalardo, G., Wandinger, U., Chaikovskaya, L., Denisov, S., Grudo, Y., Lopatsin, A., Karol, Y., Lapyonok, T., Korol, M., Osipenko, F., Savitski, D., Slesar, A., Apituley, A., Arboledas, L. A., Binietoglou, I., Kokkalis, P., Granados Muñoz, M. J., Papayannis, A., Perrone, M. R., Pietruczuk, A., Pisani, G., Rocadenbosch, F., Sicard, M., De Tomasi, F., Wagner, J., and Wang, X.: Algorithm and software for the retrieval of vertical aerosol properties using combined lidar/ radiometer data: Dissemination in EARLINET, in: Proceedings of the 26th International Laser and Radar Conference, vol. 1, Porto Heli, Greece, 25-29 June 2012, 399-402, 2012.

Chaikovsky, A., Dubovik, O., Holben, B., Bril, A., Goloub, P., Tanré, D., Pappalardo, G., Wandinger, U., Chaikovskaya, L., Denisov, S., Grudo, Y., Lopatin, A., Karol, Y., Lapyonok, T., Amiridis, V., Ansmann, A., Apituley, A., Allados-Arboledas, L., Binietoglou, I., Boselli, A., D’Amico, G., Freudenthaler, V., Giles, D., Granados-Muñoz, M. J., Kokkalis, P., Nicolae, D., Oshchepkov, S., Papayannis, A., Perrone, M. R., Pietruczuk, A., Rocadenbosch, F., Sicard, M., Slutsker, I., Talianu, C., De Tomasi, F., Tsekeri, A., Wagner, J., and Wang, X.: Lidar-Radiometer Inversion Code (LIRIC) for the retrieval of vertical aerosol properties from combined lidar/radiometer data: development and distribution in EARLINET, Atmos. Meas. Tech. Discuss., 8, 1275912822, doi:10.5194/amtd-8-12759-2015, 2015.

Choobari, O. A., Zawar-Reza, P., and Sturman, A.: The global distribution of mineral dust and its impacts on the climate system: A review, Atmos. Res., 138, 152-165, 2014.

Christensen, J. H.: The Danish Eulerian Hemispheric Model a three-dimensional air pollution model used for the Arctic, Atmos. Environ. 31, 24, 4169-4191, doi:10.1016/S13522310(97)00264-1, 1997.

Creamean, J. M., Suski, K. J., Rosenfeld, D., Cazorla, A., DeMott, P. J., Sullivan, R. C., White, A. B., Ralph, F. M., Minnis, P., Comstock, J. M., Tomlinson, J. M., and Prather, K. A.: Dust and biological aerosols from the Sahara and Asia influence precipitation in the western U.S., Science, 339, 1572-1578, doi:10.1126/science.1227279, 2013.

DeMott, P. J. and Prenni, A. J.: New directions: need for defining the numbers and sources of biological aerosols acting as ice nuclei, Atmos. Environ. , 44, 1944-1945, 2010.

Dubovik, O. and King, M. D.: A flexible inversion algorithm for retrieval of aerosol optical properties from Sun and sky radiance measurements, J. Geophys. Res.-Atmos., 105, 20673-20696, 2000.

Dubovik, O., Smirnov, A., Holben, B. N., King, M. D., Kaufman, Y. J., Eck, T. F., and Slutsker, I.: Accuracy assessments of aerosol optical properties retrieved from Aerosol Robotic Network (AERONET) Sun and sky radiance measurements, J. Geophys. Res.-Atmos., 105, 9791-9806, 2000.

Dubovik, O., Holben, B., Eck, T. F., Smirnov, A., Kaufman, Y. J., King, M. D., Tanré, D., and Slutsker, I.: Variability of absorption and optical properties of key aerosol types observed in worldwide locations, J. Atmos. Sci., 59, 590-608, 2002.

Dubovik, O., Sinyuk, A., Lapyonok, T., Holben, B. N., Mishchenko, M., Yang, P., Eck, H. Volten, T. F., Muñoz, O., and Veihelmann, B.: Application of spheroid models to account for aerosol particle nonsphericity in remote sensing of desert dust, J. Geophys. Res.Atmos., 111, D11208, doi:10.1029/2005JD006619, 2006.
Fairlie, T. D., Jacob, D. J., Dibb, J. E., Alexander, B., Avery, M. A., van Donkelaar, A., and Zhang, L.: Impact of mineral dust on nitrate, sulfate, and ozone in transpacific Asian pollution plumes, Atmos. Chem. Phys., 10, 3999-4012, doi:10.5194/acp-10-39992010, 2010.

Feingold, G., Furrer, R., Pilewskie, P., Remer, L. A., Min, Q., and Jonsson, H.: Aerosol indirect effect studies at Southern Great Plains during the May 2003 intensive operations period, J. Geophys. Res., 111, D05S14, doi:10.1029/2004JD005648, 2006.

Ferek, R. J., Garrett, T., Hobbs, P. V., Strader, S., Johnson, D., Taylor, J. P., Nielsen, K., Ackerman, A. S., Kogan, Y., and Liu, Q.: Drizzle suppression in ship tracks, J. Atmos. Sci., 57, 27072728, 2000.

Fernald, F. G.: Analysis of atmospheric lidar observations- Some comments, App. Optics, 23, 652-653, 1984.

Fernald, F. G., Herman, B. M., and Reagan, J. A.: Determination of aerosol height distributions by lidar, J. Appl. Meteorol., 11, 482-489, 1972.

Formenti, P., Schütz, L., Balkanski, Y., Desboeufs, K., Ebert, M., Kandler, K., Petzold, A., Scheuvens, D., Weinbruch, S., and Zhang, D.: Recent progress in understanding physical and chemical properties of African and Asian mineral dust, Atmos. Chem. Phys., 11, 8231-8256, doi:10.5194/acp-11-8231-2011, 2011.

Freudenthaler, V., Esselborn, M., Wiegner, M., Hesse, B., Tesche, M., Ansmann, A., Muller, D., Althausen, D., Wirth, M., Fix, A., Ehret, G., Knippertz, Pl., Toledano, C., Gasteiger, J., Garhammer, M., and Seefeldner, M.: Depolarization ratio profiling at several wavelengths in pure Saharan dust during SAMUM 2006, Tellus B, 61, 165-179, doi:10.1111/j.1600-0889.2008.00396.x, 2009.

Glen, A. and Brooks, S. D.: A new method for measuring optical scattering properties of atmospherically relevant dusts using the Cloud and Aerosol Spectrometer with Polarization (CASPOL), Atmos. Chem. Phys., 13, 1345-1356, doi:10.5194/acp-13-13452013, 2013.

Granados-Muñoz, M. J., Guerrero-Rascado, J. L., Bravo-Aranda, J. A., Navas-Guzmán, F., Valenzuela, A., Lyamani, H, Chaikovsky, A., Wandinger, U., Ansmann, A., Dubovik, O., Grudo, J. O., and Alados-Arboledas, L.: Retrieving aerosol microphysical properties by Lidar-Radiometer Inversion Code (LIRIC) for different aerosol types, J. Geophys. Res.-Atmos., 119, 4836-4858, 2014.

Granados-Muñoz, M. J., Navas-Guzmán, F., Guerrero-Rascado, J. L., Bravo-Aranda, J. A., Binietoglou, I., Pereira, S. N., Basart, S., Baldasano, J. M., Belegante, L., Chaikovsky, A., Comerón, A., D’Amico, G., Dubovik, O., Ilic, L., Kokkalis, P., MuñozPorcar, C., Nickovic, S., Nicolae, D., Olmo, F. J., Papayannis, A., Pappalardo, G., Rodríguez, A., Schepanski, K., Sicard, M., Vukovic, A., Wandinger, U., Dulac, F., and Alados-Arboledas, L.: Profiling of aerosol microphysical properties at several EARLINET/AERONET sites during July 2012 ChArMEx/EMEP campaign, Atmos. Chem. Phys. Discuss., 15, 32831-32887, doi:10.5194/acpd-15-32831-2015, 2015.

Gross, S., Tesche, M., Freudenthaler, V., Toledano, C., Wiegner, M., Ansmann, A., Althausen, D., and Seefeldner, M.: Characterization of Saharan dust, marine aerosols and mixtures of biomassburning aerosols and dust by means of multi-wavelength depolarization and Raman lidar measurements during SAMUM 2, Tellus B, 63, 706-724, doi:10.1111/j.1600-0889.2011.00556.x, 2011. 
Guerrero-Rascado, J. L., Ruiz, B., and Alados-Arboledas, L.: Multispectral Lidar characterization of the vertical structure of Saharan dust aerosol over southern Spain, Atmos. Environ., 42, 26682681, 2008.

Guerrero-Rascado, J. L., Olmo, F. J., Avilés-Rodrìguez, I., NavasGuzmán, F., Pérez-Ramírez, D., Lyamani, H., and Alados Arboledas, L.: Extreme Saharan dust event over the southern Iberian Peninsula in september 2007: active and passive remote sensing from surface and satellite, Atmos. Chem. Phys., 9, 84538469, doi:10.5194/acp-9-8453-2009, 2009.

Guerrero-Rascado, J. L., Landulfo, E., Antuña, J. C., Barbosa, H. M. J., Barja, B., Bastidas, A. E., Bedoya, A. E., da Costa, R., Estevan, R., Forno, R. N., Gouveia, D. A., Jiménez, C., Larroza, E. G., Lopes, F. J. S., Montilla-Rosero, E., Moreira, G. A., Nakaema, W. M., Nisperuza, D., Otero, L., Pallotta, J. V., Papandrea, S., Pawelko, E., Quel, E. J., Ristori, P., Rodrigues, P. F., Salvador, J., Sánchez, M. F., and Silva, A.: Towards an instrumental harmonization in the framework of LALINET: dataset of technical specifications, Proc. SPIE 2014, 9246, 92460O-1—92460O14, doi:10.1117/12.2066873, 2014.

Holben, B. N., Eck, T. F., Slutsker, I., Tanre, D., Buis, J. P., Setzer, A., Vermote, E., Reagan, J. A., Kaufman, Y. J., Nakajima, T., Lavenu, F., Jankowiak, I., and Smirnov, A.: AERONET-A Federated Instrument Network and Data Archive for Aerosol Characterization, Remote. Sens. Environ., 66, 1-16, 1998.

Kazadzis, S., Veselovskii, I., Amiridis, V., Gröbner, J., Suvorina, A., Nyeki, S., Gerasopoulos, E., Kouremeti, N., Taylor, M., Tsekeri, A., and Wehrli, C.: Aerosol microphysical retrievals from precision filter radiometer direct solar radiation measurements and comparison with AERONET, Atmos. Meas. Tech., 7, 20132025, doi:10.5194/amt-7-2013-2014, 2014.

Klett, J. D.: Stable analytical inversion solution for processing lidar returns, Appl. Optics, 20, 211-220, 1981

Levy, R. C., Mattoo, S., Munchak, L. A., Remer, L. A., Sayer, A. M., Patadia, F., and Hsu, N. C.: The Collection 6 MODIS aerosol products over land and ocean, Atmos. Meas. Tech., 6, 29893034, doi:10.5194/amt-6-2989-2013, 2013.

Lopatin, A., Dubovik, O., Chaikovsky, A., Goloub, P., Lapyonok, T., Tanré, D., and Litvinov, P.: Enhancement of aerosol characterization using synergy of lidar and sun-photometer coincident observations: the GARRLiC algorithm, Atmos. Meas. Tech., 6, 2065-2088, doi:10.5194/amt-6-2065-2013, 2013.

Lyamani, H., Olmo, F. J., and Alados-Arboledas, L.: Light scattering and absorption properties of aerosol particles in the urban environment of Granada, Spain, Atmos. Environ., 42, 2630-2642, 2008.

Lyamani, H., Olmo, F. J., and Alados-Arboledas, L.: Physical and optical properties of aerosols over an urban location in Spain: seasonal and diurnal variability, Atmos. Chem. Phys., 10, 239254, doi:10.5194/acp-10-239-2010, 2010.

Lyamani, H., Fernández-Gálvez, J., Pérez-Ramírez, D., Valenzuela, A., Antón, M., Alados, I., Titos, G., Olmo, F. J., and AladosArboledas, L.: Aerosol properties over two urban sites in South Spain during an extended stagnation episode in winter season, Atmos. Environ., 62, 424-432, 2012.

Mamouri, R. E. and Ansmann, A.: Fine and coarse dust separation with polarization lidar, Atmos. Meas. Tech., 7, 3717-3735, doi:10.5194/amt-7-3717-2014, 2014.
McConnell, C. L., Formenti, P., Highwood, E. J., and Harrison, M. A. J.: Using aircraft measurements to determine the refractive index of Saharan dust during the DODO Experiments, Atmos. Chem. Phys., 10, 3081-3098, doi:10.5194/acp-10-30812010, 2010.

Mie, G.: Beiträge zur Optik trüber Medien, speziell kolloidaler Metallösungen, Annalen der Physik, 330.3, 377-445, 1908.

Miller, R. L. and Tegen, I.: Climate response to soil dust aerosols, J. Climate, 11, 3247-3267, 1998.

Mishchenko, M. I., Travis, L. D., Kahn, R. A., and West, R. A.: Modeling phase functions for dust like tropospheric aerosols using a shape mixture of randomly oriented polydisperse spheroids, J. Geophys. Res., 102, 16831-16848, 1997.

Müller, D., Wandinger, U., and Ansmann, A.,: Microphysical particle parameters from extinction and backscatter lidar data by inversion with regularization: theory, Appl. Optics, 38, 2346-2357, 1999.

Müller, D., Veselovskii, I., Kolgotin, A., Tesche, M., Ansmann, A., and Dubovik, O.: Vertical profiles of pure dust and mixed smoke-dust plumes inferred from inversion of multiwavelength Raman/polarization lidar data and comparison to AERONET retrievals and in situ observations, Appl. Optics, 52, 3178-3202, 2013.

Navas-Guzmán, F., Guerrero-Rascado, J. L., and Alados-Arboledas, L.: Retrieval of the lidar overlap function using Raman signals, Opt. Pura Apl., 44, 71-75, 2011.

Navas-Guzmán, F., Bravo-Aranda, J. A., Guerrero-Rascado, J. L., Granados-Muñoz, M. J., and Alados-Arboledas, L.: Statistical analysis of aerosol optical properties retrieved by Raman lidar over Southeastern Spain, Tellus B, 65, 21234, doi:10.3402/tellusb.v65i0.21234, 2013.

Nicolet, M., Stetrzer, O., and Lohmann, U.: Depolarization ratios of singles ice particles assuming finite circular cylinders, Appl. Optics, 46, 4465-4476, 2007.

Nicolet, M., Stetzer, O., Lüönd, F., Möhler, O., and Lohmann, U.: Single ice crystal measurements during nucleation experiments with the depolarization detector IODE, Atmos. Chem. Phys., 10, 313-325, doi:10.5194/acp-10-313-2010, 2010.

Nicolet, M., Schnaiter, M., and Stetzer, O.: Circular depolarization ratios of single water droplets and finite ice circular cylinders: a modeling study, Atmos. Chem. Phys., 12, 4207-4214, doi:10.5194/acp-12-4207-2012, 2012.

Olmo, F. J., Quirantes, A., Alcántara, A., Lyamani, H., and AladosArboledas, L.: Preliminary results of a non-spherical aerosol method for the retrieval of the atmospheric aerosol optical properties, J. Quant. Spectrosc. Ra., 100, 305-314, 2006.

O’Neill, N. T., Dubovik, O., and Eck, T. F.: Modified Ångström exponent for the characterization of submicrometer aerosols, Appl Optics, 40, 2368-2375, 2001a.

O’Neill, N. T., Eck, T. F., Holben, B., Smirnov, A., and Dubovik, O.: Bimodal size distribution influences on the variation of Angstrom derivatives in spectral and optical depth space, J. Geophys. Res. 106, 9787-9806, 2001b.

O’Neill, N. T., Eck, T. F., Smirnov, A., Holben, B. N., and Thulasiraman, S.: Spectral discrimination of coarse and fine mode optical depth, J. Geophys. Res.-Atmos., 108, 4559, doi:10.1029/2002JD002975, 2003.

Papayannis, A., Mamouri, R. E., Amiridis, V., Remoundaki, E., Tsaknakis, G., Kokkalis, P., Veselovskii, I., Kolgotin, A., Nenes, 
A., and Fountoukis, C.: Optical-microphysical properties of Saharan dust aerosols and composition relationship using a multi-wavelength Raman lidar, in situ sensors and modelling: a case study analysis, Atmos. Chem. Phys., 12, 4011-4032, doi:10.5194/acp-12-4011-2012, 2012.

Pappalardo, G., Amodeo, A., Pandolfi, M., Wandinger, U., Ansmann, A., Bösenberg, J., Matthias, V., Amiridis, V., De Tomasi, F., and Frioud, M.: Aerosol lidar intercomparison in the framework of the EARLINET project. 3. Raman lidar algorithm for aerosol extinction, backscatter, and lidar ratio, Appl. Optics, 43, 5370-5385, 2004.

Pappalardo, G., Amodeo, A., Apituley, A., Comeron, A., Freudenthaler, V., Linné, H., Ansmann, A., Bösenberg, J., D’Amico, G., Mattis, I., Mona, L., Wandinger, U., Amiridis, V., AladosArboledas, L., Nicolae, D., and Wiegner, M.: EARLINET: towards an advanced sustainable European aerosol lidar network, Atmos. Meas. Tech., 7, 2389-2409, doi:10.5194/amt-7-23892014, 2014.

Pérez, C., Nickovic, S., Pejanovic, G., Baldasano, J. M., and Özsoy, E.: Interactive dust-radiation modeling: a step to improve weather forecasts, J. Geophys. Res., 111, D16206, doi:10.1029/2005JD006717, 2006a.

Pérez, C., Nickovic, S., Baldasano, J. M., Sicard, M., Rocadenbosch, F., and Cachorro, V. E.: A long Saharan dust event over the western Mediterranean: lidar, Sun photometer observations, and regional dust modeling?, J. Geophys. Res., 111, D15214, doi:10.1029/2005JD006579, 2006b.

Pérez-Ramírez, D., Aceituno, J., Ruiz, B., Olmo, F. J., and AladosArboledas, L.: Development and calibration of a star-photometer to measure the aerosol optical depth: Smoke observations at a high mountain site, Atmos. Environ., 42, 2733-2738, 2008a.

Pérez-Ramírez, D., Aceituno, J., Ruiz, B., Olmo, F. J., and AladosArboledas, L.: Application of Sun/star photometry to derive the aerosol optical depth, Int. J. Remote Sens., 29, 5113-5132, 2008b.

Pérez-Ramírez, D., Lyamani, H., Olmo, F. J., and Alados Arboledas, L.: Improvements in star photometry for aerosol characterizations, J. Aerosol Sci., 4, 737-745, 2011.

Pérez-Ramírez, D., Lyamani, H., Olmo, F. J., Whiteman, D. N., and Alados-Arboledas, L.: Columnar aerosol properties from sunand-star photometry: statistical comparisons and day-to-night dynamic, Atmos. Chem. Phys., 12, 9719-9738, doi:10.5194/acp12-9719-2012, 2012a.

Pérez-Ramírez, D., Lyamani, H., Olmo, F. J., Whiteman, D. N., Navas-Guzmán, F., and Alados-Arboledas, L.: Cloud screening and quality control algorithm for star photometer data: assessment with lidar measurements and with all-sky images, Atmos. Meas. Tech., 5, 1585-1599, doi:10.5194/amt-5-1585-2012, 2012b.

Pérez-Ramírez, D., Veselovskii, I., Whiteman, D. N., Suvorina, A., Korenskiy, M., Kolgotin, A., Holben, B., Dubovik, O., Siniuk, A., and Alados-Arboledas, L.: High temporal resolution estimates of columnar aerosol microphysical parameters from spectrum of aerosol optical depth by linear estimation: application to long-term AERONET and star-photometry measurements, Atmos. Meas. Tech., 8, 3117-3133, doi:10.5194/amt-8-3117-2015, 2015.

Rodríguez, S., Alastuey, A., Alonso-Pérez, S., Querol, X., Cuevas, E., Abreu-Afonso, J., Viana, M., Pérez, N., Pandolfi, M., and de la Rosa, J.: Transport of desert dust mixed with North African industrial pollutants in the subtropical Saharan Air Layer, Atmos. Chem. Phys., 11, 6663-6685, doi:10.5194/acp-11-66632011, 2011.

Rosenberg, P. D., Dean, A. R., Williams, P. I., Dorsey, J. R., Minikin, A., Pickering, M. A., and Petzold, A.: Particle sizing calibration with refractive index correction for light scattering optical particle counters and impacts upon PCASP and CDP data collected during the Fennec campaign, Atmos. Meas. Tech., 5, 1147-1163, doi:10.5194/amt-5-1147-2012, 2012.

Rosenfeld, D., Rudich, Y., and Lahav, R.: Desert dust suppressing precipitation: A possible desertification feedback loop, P. Natl. Acad. Sci. USA, 98, 5975-5980, 2001.

Schnaiter, M., Büttner, S., Möhler, O., Skrotzki, J., Vragel, M., and Wagner, R.: Influence of particle size and shape on the backscattering linear depolarisation ratio of small ice crystals - cloud chamber measurements in the context of contrail and cirrus microphysics, Atmos. Chem. Phys., 12, 10465-10484, doi:10.5194/acp-12-10465-2012, 2012.

Seifert, P., Ansmann, A., Mattis, I., Wandinger, U., Tesche, M., Engelmann, R., Müller, D., Pérez, C., and Haustein, K.:, Saharan dust and heterogeneous ice formation: Eleven years of cloud observations at a central European EARLINET site, J. Geophys. Res.-Atmos, 115, D20201, doi:10.1029/2009JD013222, 2010.

Shao, Y., Wyrwoll, K. H., Chappell, A., Huang, J., Lin, Z., McTainsh, G. H., Mikami, M., Tanaka, T., Wang, X., and Yoon, S.: Dust cycle: An emerging core theme in Earth system science, Aeolian Research, 2, 181-204, 2011.

Textor, C., Schulz, M., Guibert, S., Kinne, S., Balkanski, Y., Bauer, S., Berntsen, T., Berglen, T., Boucher, O., Chin, M., Dentener, F., Diehl, T., Feichter, J., Fillmore, D., Ginoux, P., Gong, S., Grini, A., Hendricks, J., Horowitz, L., Huang, P., Isaksen, I. S. A., Iversen, T., Kloster, S., Koch, D., Kirkevåg, A., Kristjansson, J. E., Krol, M., Lauer, A., Lamarque, J. F., Liu, X., Montanaro, V., Myhre, G., Penner, J. E., Pitari, G., Reddy, M. S., Seland, Ø., Stier, P., Takemura, T., and Tie, X.: The effect of harmonized emissions on aerosol properties in global models an AeroCom experiment, Atmos. Chem. Phys., 7, 4489-4501, doi:10.5194/acp-7-4489-2007, 2007.

Titos, G., Foyo-Moreno, I., Lyamani, H., Querol, X., Alastuey, A., and Alados-Arboledas, L.: Optical properties and chemical composition of aerosol particles at an urban location: An estimation of the aerosol mass scattering and absorption efficiencies, J. Geophys. Res.-Atmos., 117, D04206, doi:10.1029/2011JD016671, 2012.

Titos, G., Lyamani, H., Pandolfi, M., Alastuey, A., and AladosArboledas L.: Identification of fine $\left(\mathrm{PM}_{1}\right)$ and coarse $\left(\mathrm{PM}_{10-1}\right)$ sources of particulate matter in an urban environment, Atmos. Environ., 89, 593-602, 2014.

Twohy, C. H., Kreidenweis, S. M., Eidhammer, T., Browell, E. V., Heymsfield, A. J., Bansemer, A. R., Anderson, B. E., Chen, G., Ismail, S., and DeMott, P. J.: Saharan dust particles nucleate droplets in eastern Atlantic clouds, Geophys. Res. Lett., 36, L01807, doi:10.1029/2008GL035846, 2009.

Valenzuela, A., Olmo, F. J., Lyamani, H., Antón, M., Quirantes, A., and Alados-Arboledas, L.: Aerosol radiative forcing during African desert dust events (2005-2010) over Southeastern Spain, Atmos. Chem. Phys., 12, 10331-10351, doi:10.5194/acp12-10331-2012, 2012a. 
Valenzuela, A., Olmo, F. J., Lyamani, H., Antón, M., Quirantes, A., and Alados-Arboledas, L.: Analysis of the columnar radiative properties retrieved during African desert dust events over Granada (2005-2010) using principal plane sky radiances and spheroids retrieval procedure, Atmos. Res., 104, 292-301, 2012b.

Valenzuela, A., Olmo, F. J., Lyamani, H., Antón, M., Quirantes, A., and Alados-Arboledas, L.: Classification of aerosol radiative properties during African desert dust intrusions over southeastern Spain by sector origins and cluster analysis, J. Geophys. Res.Atmos., 117, D06214, doi:10.1029/2011JD016885, 2012c.

Veselovskii, I., Kolgotin, A., Griaznov, V., Müller, D., Wandinger, U., and Whiteman, D. N.: Inversion with regularization for the retrieval of tropospheric aerosol parameters from multiwavelength lidar sounding, Appl. Optics, 41, 3685-3699, 2002.

Veselovskii, I., Kolgotin, A., Griaznov, V., Müller, D., Franke, K., and Whiteman, D.N.: Inversion of multiwavelength Raman lidar data for retrieval of bimodal aerosol size distribution, Appl. Optics, 43, 1180-1195, 2004.

Veselovskii, I., Dubovik, O., Kolgotin, A., Lapyonok, T., Di Girolamo, P., Summa, D., Whiteman, D.N., Mischenko, M., and Tanre, D.: Application of randomly oriented spheroids for retrieval of dust particle parameters from multiwavelength lidar measurements, J. Geophys. Res., 115, D21203, doi:10.1029/2010JD014139, 2010.

Veselovskii, I., Dubovik, O., Kolgotin, A., Korenskiy, M., Whiteman, D. N., Allakhverdiev, K., and Huseyinoglu, F.: Linear estimation of particle bulk parameters from multi-wavelength lidar measurements, Atmos. Meas. Tech., 5, 1135-1145, doi:10.5194/amt-5-1135-2012, 2012.

Veselovskii, I., Whiteman, D. N., Korenskiy, M., Kolgotin, A., Dubovik, O., Pérez-Ramírez, D., and Suvorina, A.: Retrieval of spatio-temporal distributions of particle parameters from multiwavelength lidar measurements using the linear estimation technique and comparison with AERONET, Atmos. Meas. Tech., 6, 2671-2682, doi:10.5194/amt-6-2671-2013, 2013.
Volckens, J. and Peters, T. M.: Counting and particle transmission efficiency of the aerodynamic particle sizer, J. Aerosol Sci., 36, 1400-1408, 2005.

Volten, H., Munoz, O., Rol, E., De Haan, J. F., Vassen, W., Hovenier, J. W., Muinonen, K., and Nousiainen, T.: Scattering matrices of mineral aerosol particles at $441.6 \mathrm{~nm}$ and $632.8 \mathrm{~nm}$, J. Geophys. Res., 106, 17375-17402, 2001.

Wagner, J., Ansmann, A., Wandinger, U., Seifert, P., Schwarz, A., Tesche, M., Chaikovsky, A., and Dubovik, O.: Evaluation of the Lidar/Radiometer Inversion Code (LIRIC) to determine microphysical properties of volcanic and desert dust, Atmos. Meas Tech., 6, 1707-1724, doi:10.5194/amt-6-1707-2013, 2013.

Wandinger, U. and Ansmann, A.: Experimental determination of the lidar overlap profile with Raman lidar, Appl. Optics, 41, 511514, 2002.

Weinzierl, B., Petzold, A., Esselborn, M., Wirth, M., Rasp, K., Kandler, K., Schütz, L., Koepke, P., and Fiebig, M.: Airborne measurements of dust layer properties, particle size distribution and mixing state of Saharan dust during SAMUM 2006. Tellus B, 61, 96-117, doi:10.1111/j.1600-0889.2008.00392.x, 2009.

Zender, C. S., Bian, H., and Newman, D.: Mineral Dust Entrainment and Deposition (DEAD) model: Description and 1990s dust climatology, J. Geophys. Res., 108, 4416, doi:10.1029/2002JD002775, 2003.

Zender, C. S., Miller, R., and Tegen, I.: Quantifying mineral dust mass budgets: Terminology, constraints, and current estimates, EOS T. Am. Geophys. Un., 85, 509-512, 2004. 